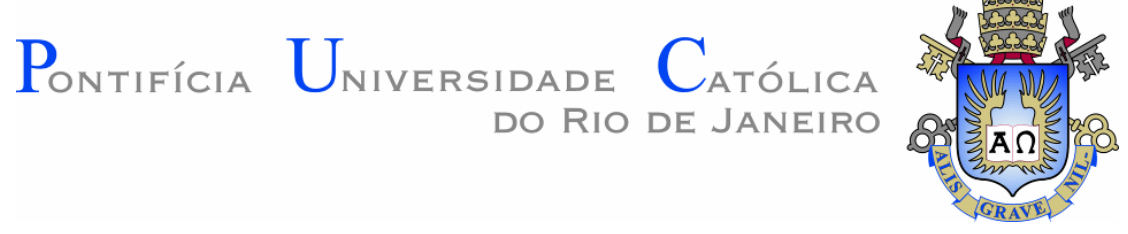

Paulo Vieira da Silva Magalhães

\title{
Autonomia, Autoridade e Individualismo. \\ O mito da autoria no Campo do Design
}

Dissertação de Mestrado

Dissertação apresentada como requisito parcial para obtenção do grau de mestre pelo Programa de PósGraduação em Design do departamento de Artes e Design da PUC-Rio.

Orientador: Prof. Alberto Cipiniuk

Rio de Janeiro Janeiro de 2020 


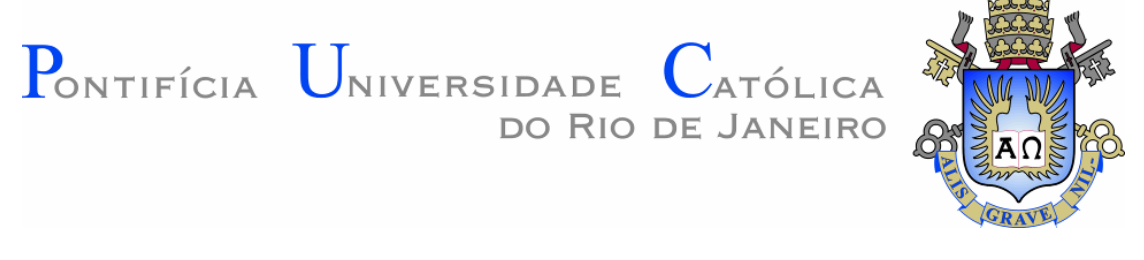

Paulo Vieira da Silva Magalhães

\title{
Autonomia, Autoridade e Individualismo O mito da autoria no Campo do Design
}

Dissertação apresentada como requisito parcial para obtenção do grau de mestre pelo Programa de PósGraduação em Design do da PUC-Rio aprovada pela comissão examinadora abaixo.

\author{
Prof. Alberto Cipiniuk \\ Orientador \\ Departamento de Artes \& Design - PUC-Rio \\ Profa. Denise Berruezo Portinari \\ Departamento de Artes \& Design - PUC-Rio \\ Profa. Irina Aragão dos Santos \\ Departamento de Artes \& Design - PUC-Rio \\ Profa. Fabiana Oliveira Heinrich \\ Escola de Belas Artes - UFRJ
}

Rio de Janeiro, 16 de janeiro de 2020 
Todos os direitos reservados. É proibida a reprodução total ou parcial do trabalho sem autorização da universidade, do autor e do orientador.

\section{Paulo Vieira da Silva Magalhães}

Bacharel em Design Gráfico pela Universidade Federal de Pelotas - UFPEL (2014). Durante a faculdade foi bolsista pelo grupo PET Artes Visuais (2011-2014). Estagiário como Diretor de Arte na empresa Me Gusta - Propaganda e Novas Possibilidades no ano de 2014. Diretor de Arte na empresa Me Gusta - Propaganda e Novas Possibilidades nos ano de 2014-2016.

Ficha Catalográfica

Magalhães, Paulo Vieira da Silva
Autonomia, autoridade e individualismo : o mito da
autoria no campo do Design / Paulo Vieira da Silva
Magalhães ; orientador: Alberto Cipiniuk. - 2020.
91 f. ; $30 \mathrm{~cm}$
Dissertação (mestrado)-Pontifícia Universidade
Católica do Rio de Janeiro, Departamento de Artes e Design,
2020. $\quad$ Inclui bibliografia
1. Artes e Design - Teses. 2. Campo do Design. 3.
4. Autoria. I. Cipiniuk, Alberto. II. Pontifícia
Crítica.
Universidade Católica do Rio de Janeiro. Departamento de
Artes e Design. III. Título.

CDD: 700 


\section{Agradecimentos}

Foram muitas as pessoas e instâncias envolvidas nestes dois anos de trabalho, às quais devo agora meus sinceros agradecimentos.

De sobremaneira, agradeço ao meu orientador Professor Alberto Cipiniuk, que me ensinou a pensar criticamente, além de fornecer um exemplo de elevado padrão intelectual. Além de orientar este trabalho com atenção e constante presença, o Mestre se revelou um verdadeiro amigo. Ao Prof. Alberto, serei eternamente grato.

Agradeço ao Departamento de Artes e Design da PUC-Rio pela possibilidade de desenvolvimento deste estudo, sobretudo pelo imprescindível financiamento através das bolsas VRAC e CNPQ.

Aos professores da banca, Profa. Denise Berruezo Portinari, Profa. Irina Aragão dos Santos e Profa. Fabiana Heinrich, agradeço pelo interesse em avaliar e debater sobre este trabalho. A leitura atenta e os comentários edificam este estudo, que não é pensado, de forma alguma, individualmente. A essas três professoras agradeço ainda pela amizade construída ao longo da pesquisa. Tenho muito gosto em afirmar que nossa amizade e luta se estenderam para fora dos limites do âmbito acadêmico.

Agradeço à Profa. Lúcia Bergamaschi Costa Weymar por acreditar na minha capacidade em voltar para a academia e pela notável gentileza e amizade, ao saber que me mudaria de Pelotas/RS para o Rio de Janeiro/RJ, se colocando de prontidão para me indicar profissionais atuantes aqui na cidade do Rio. De igual forma, agradeço pela segunda vez à Profa. Fabiana Heinrich que (com a mesma gentileza da Profa. Lúcia), mesmo sem me conhecer direito, à época, não hesitou em me apresentar para o Prof. Alberto Cipiniuk.

Agradeço aos funcionários do Departamento de Artes e Design da PUC-Rio, sobretudo Diego Pimenta e Romário César, pelos também auxílios burocráticos na realização desta pesquisa. 
Agradeço à minha esposa, Anne Sparremberger, pelo carinho, amor e paciência durante estes dois anos de pesquisa, sendo sempre meu "porto seguro" quando precisei.

Agradeço, por fim, à minha família, que sempre acreditou em mim de maneira plena e irrestrita. 


\section{Resumo}

Magalhães, Paulo Vieira da Silva; Cipiniuk, Alberto (Orientador). Autonomia, Autoridade e Individualismo: O mito da Autoria no Campo do Design. Rio de Janeiro, 2019. 91 p. Dissertação de Mestrado Departamento de Artes e Design, Pontifícia Universidade Católica do Rio de Janeiro.

Nesta dissertação examina-se a autoria no Campo do Design. Argumenta-se que a noção de autoria adotada hegemonicamente pelo campo é carismática. É dizer, os pares do campo defendem a existência de um dom extraordinário e obscuro concedido para alguém que servirá para o bem do seu grupo social, enxerga o designer autor como aquele agente que, através da inovação e da criatividade, constrói seus objetos e/ou imagens de modo autoritário, autônomo e individual, sem nenhuma interferência externa. Considera-se que esta visão advém do Campo da Arte, visto que o Campo do Design "herdou" muitas noções do Campo da Arte, e que ainda existe uma incerteza sobre o que pertence a um campo e o que pertence ao outro. Ademais, percebe-se que os agentes de legitimação do Campo do Design por muitas vezes não consideram o modo de produção vigente, o capitalismo, e que neste modo de produção o que se produz são mercadorias estas projetadas pelo Campo do Design - que não possuem apenas valor de uso, mas principalmente valor de troca simbólica. Assim, se estuda as transformações históricas que ocorreram no Campo da Arte no que diz respeito à autoria para entender como as noções que permeiam o Campo da Arte foram "herdadas" pelo Campo do Design e como estas noções foram se transformando e se reproduzindo ao longo do período moderno, de forma a fazer uma crítica a tais noções, que se julga aqui serem passadistas. Assim sendo, se propõe que o designer como autor é uma forma de produzir capital simbólico no Campo do Design, e que a promessa de autoria promovida nas escolas de design produz alienação, e que tal alienação não condiz com a necessidade social.

\section{Palavras-chave}

Campo do Design; crítica; autoria. 
Abstract

Magalhães, Paulo Vieira da Silva; Cipiniuk, Alberto (Advisor). Autonomy, Authority and Individualism: The Myth of Authorship in the Design Field. Rio de Janeiro, 2019. 91 p. Dissertação de Mestrado - Departamento de Artes e Design, Pontifícia Universidade Católica do Rio de Janeiro.

This dissertation examines the authorship in the Field of Design. It is argued that the notion of authorship hegemonically adopted by the field is charismatic, that is, it sees the designer author as that agent who, through innovation and creativity, builds his objects and/or images in an authoritarian, autonomous and individual way, without no outside interference. This view is considered to come from the Art Field, since the Design Field has "inherited" many notions from the Art Field, and there is still uncertainty about what belongs to one field and what belongs to the other. Moreover, it is clear that the legitimating agents of the Design Field often do not consider the current mode of production, capitalism, and that in this mode of production what they produce are commodities - these designed by the Design Field - that do not have only use value, but mainly symbolic exchange value. Thus, we study the historical transformations that occurred in the field of art with regard to authorship to understand how the notions that permeate the field of art were "inherited" by the Field of Design and how these notions were transformed and reproduced to throughout the modern period, in order to make a critique of such notions, which are thought here to be outdated. Therefore, it is proposed that the designer as an author is a way of producing symbolic capital in the Field of Design, and that the promise of authorship promoted in the design schools produces alienation, and that such alienation does not match social needs.

\section{Keywords}

Field of Design; critique; authorship. 


\section{Sumário}

1. INTRODUÇÃO 9

2. O surgimento da noção de autoria 17

2.1. Uma breve história da autoria no Campo da Arte 17

2.2. O Sujeito sujeito de si mesmo 22

2.3. O ato social é sempre um ato coletivo 26

3. A violência simbólica e o fetichismo da mercadoria: a manutenção do pensamento acrítico no Campo do Design 32

3.1. O Campo do Design: um esporte de combate 32

3.2. A Violência Simbólica no estudo de design 38

3.3. O fetichismo da mercadoria no trabalho do designer 41

4. Toda escolha estética é uma escolha política 46

4.1. Uma brevíssima história da Estética 47

5. Crítica do design autoral 59

5.1. Uma apresentação à noção hegemônica da autoria no Campo do $\begin{array}{ll}\text { Design } & 60\end{array}$

5.2. O autor como produtor: idealismo em Benjamin e Lupton 72

6. Conclusão 82

$\begin{array}{lr}\text { 7. Referências Bibliográficas } & 89\end{array}$ 


\section{INTRODUÇÃO}

No Campo do Design, tal como no Campo da Arte, quase que na totalidade das vezes, trata-se a questão da autoria de uma forma passadista. Verifica-se um tipo de análise na qual o designer ${ }^{1}$ se personifica como o único criador, autor "original" e, com total autonomia e autoridade sobre seus projetos, desenvolve produtos que julga inovadores, isto é, pensados, projetados e realizados individualmente, sem nenhuma interferência externa, transformando tudo aquilo que existia antes em algo absolutamente novo. Essa noção parece ser hegemônica no campo, desconsiderando o modo de produção da sociedade industrial, o Capitalismo, sistema econômico em que todos os produtos industriais são estandardizados, além de sua principal função social, por princípio, ser a produção do lucro. Os designers afirmam que os objetos que produzem são absolutamente funcionais ou utilitários esquecendo-se, contudo, que servem principalmente para atender às pessoas que são denominadas de usuários. $^{2}$ Verifica-se também e, acima de tudo, que silenciam sobre o fato de que os objetos industriais são mercadorias, isto é, que são objetos com valor de troca simbólica e não apenas valor de uso. Os objetos são fabricados para a concomitante produção de mais-valor. Ademais, de modo paradoxal, é importante ressaltar, os designers insistem em dizer que sua maior preocupação é com o usuário e talvez essa afirmação seja a maior prova de que são indiferentes às pessoas que adquirem seus produtos ou mercadorias, afinal as mercadorias não são para serem usadas, mas para serem trocadas.

Verifica-se empiricamente que existe uma recorrente especulação sobre a independência da categoria profissional do design em relação ao mundo que a cerca, pois o design é considerado como se fosse uma atividade contemplativa ou espiritual. Para alguns pares do campo, a prática do design não é uma forma de

\footnotetext{
${ }^{1}$ Utiliza-se aqui o termo "design" ou "designer" em itálico como uma opção política. Além do anglicanismo, que já torna por si só o termo "design" confuso, defende-se na ora dissertação que é um campo que não possui estatutos ontológicos e epistemológicos concretos claramente definidos. ${ }^{2}$ Assim como na nota acima, utiliza-se aqui o termo usuário em itálico como uma opção política. É dizer, o usuário e o estudo acerca desse no Campo do Design é uma noção romântica: o usuário é um eufemismo para a palavra "consumidor", assim como se utiliza de eufemismos similares para chamar o "empregado" de colaborador e assim por diante.
} 
trabalho como outra qualquer, mas um "fazer", uma "realização" ou uma "atividade", mas quase nunca um "trabalho". Na maioria das vezes a noção de design se aproxima de uma ideia carismática em relação ao trabalho dos designers, isto é, eles não são vistos como trabalhadores, mas como "autores". Os designers seriam produtores de "obras", tal como os artistas que, a partir do nada, trazem à luz $z^{3}$ projetos completamente inovadores, criados apenas pela inspiração de pessoas dotadas de capacidades únicas e inatas, tal como a noção medieval Deus artifex, Deus como divino artesão. ${ }^{4}$ Acontece que a realidade não é tão otimista. Com frequência, percebe-se que os designers estão preocupados em descrever os seus métodos, as suas técnicas, e isso acaba por obscurecer o fato de que o design envolve muito mais do que apenas o trabalho produzido por designers. Isso acaba por criar uma falsa impressão de que são apenas e unicamente esses os responsáveis pelos resultados atingidos. Por mais que sejam os designers os responsáveis por projetar a mercadoria, quem dá "carta branca" para que os mesmos sejam de fato desenvolvidos são os diretores das indústrias e empresários. Tanto é assim que no desenvolvimento de uma manufatura é comum que se prepare muitos designs preliminares, os quais apenas um será escolhido pelo empresário (FORTY, 2007, p. 324).

Forty (2007) afirma que é o empresário, o dono do negócio ou da indústria, que decide qual o design que encarna mais satisfatoriamente as ideias necessárias para o sucesso do produto. E que é ele, o empresário, que seleciona a forma da mercadoria a ser fabricada. Ademais, para Forty, os designers costumam falar e escrever apenas sobre o que eles mesmos fazem, colocando o design como algo que pertence totalmente ao domínio do designer. Ele afirma, ainda, que esse equívoco reaparece em inúmeros livros e na cobertura do design nas mídias, gerando consequências graves, como o ensino dessa noção nas escolas de design, em que os estudantes correm o risco de adquirir ilusões grandiosas acerca da natureza de seu trabalho e ficar frustrados em suas carreiras subsequentes (FORTY, 2007, p. 325).

Sustenta-se que essa onipotência, reproduzida de modo sistemático e em larga escala, isto é, ensinada nas escolas de design, é uma fantasia: o mito da

\footnotetext{
${ }^{3}$ Quando se emprega o termo trazer à luz, estamos fazendo referência ao Velho Testamento, Gênesis 1: 3, à expressão latina fiat lux, "faça-se a luz", "que haja a luz", ordenações fundadoras realizada diretamente pelo criador.

${ }^{4}$ DAVIS, Rebeca. Piers Plowman and the Book of Nature. Oxford: Oxford University Press, 2016, p. 103.
} 
autonomia criativa faz esquecer o problema da ideologia como determinante no design e liberta os designers da situação incômoda de que talvez não sejam mais do que atores no teatro da história. Trata-se de uma crença difundida de que, apesar da existência de provas em contrário, os indivíduos são os senhores de sua vontade e seu destino (FORTY, 2007, p. 326). Não é raro observar os próprios designers cheios de orgulho de suas criações, como se fossem eles os únicos responsáveis por elas, esquecendo-se que por trás da manufatura de um produto existem inúmeros fatores que não são decididos pelo designer.

Para grande parte dos designers, não se resolve os problemas com teoria, mas num conchavo com o mito de seu próprio poder e no total desconhecimento que agem como meros agentes da ideologia burguesa. O mais comum é que os designers descrevam seus trabalhos como se tivessem total onipotência sobre eles (Idem., p. $325)$.

De uma posição contrária ao hegemônico, defende-se com a presente dissertação que o objeto de design deve ser entendido como manufatura, isto é, resultado de uma prática, um modo de trabalho como qualquer outro. Trabalho é uma forma organizada de produção, que tem a ver com uma demanda social. Assim o trabalho de um designer não difere do trabalho de um médico ou de um advogado, ou de qualquer outra forma de trabalho exercida por qualquer outro tipo de trabalhador, e não apenas por profissionais liberais. Parece claro que todo trabalho é específico, mas os designers e suas corporações profissionais não definem isso que é específico no trabalho do design. Qual é a sua singularidade? Qual a especificidade que um designer precisa deter para ser considerado designer? Essas são algumas das discussões pretendidas para esta dissertação.

Existe ainda um desnível entre a noção tradicional, a qual se distingue do que se chama de "produção social", que possui uma tendência mais politizada ${ }^{5}$, no sentido de como se estabelecem as relações humanas dentro da sociedade industrial, marcada por uma relação de competitividade. Autoria só existe porque hegemonicamente naturalizou-se no Campo do Design tal noção, em que uma pessoa é melhor do que a outra. Quem consagra esta noção de que existe, em alguma medida, alguém que é superior a outro? Por que existe a questão autoral no Campo

\footnotetext{
5 Aqui cabe esclarecer que o termo "politizado" tem a ver com as relações humanas e sociais que ocorrem na polis, isto é, na sociedade, e não de um ponto de vista político-partidário.
} 
do Design? Supõe-se, decerto, porque os profissionais necessitam de uma identidade, e até onde se pode verificar essa identidade foi apropriada do Campo da Arte. A fronteira do Campo do Design e do Campo da Arte parece ser, por vezes, porosa, flexível, permeável, de modo que por muitas vezes não se tem a clareza se está a falar de arte ou design.

Diante do até aqui exposto, a pesquisa pretendida será baseada no seguinte problema: Quais as influências e consequências das noções hegemônicas idealistas do Design Autoral na Sociedade Industrial para a construção do estatuto epistemológico vigente do Campo do Design? A proposta será discutir essa questão, partindo do pressuposto de que os designers não estão colaborando para a construção de uma teoria crítica no Campo do Design. Isto porque produzem objetos com pouca (ou até mesmo destituídos de) serventia social, justamente por acreditarem em noções passadistas e carismáticas da individualidade, autoridade e carência de identidade que a questão autoral atual impõe.

Percebe-se que tais noções apenas tangenciam o nível da aparência de como as coisas acontecem de fato e daí se propõe que se aproxime tais noções ao nível de sua verdadeira natureza, e aqui já procura-se apresentar um ponto de vista mais politizado, como o do Materialismo Histórico de Karl Marx e Friedrich Engels e das noções de Campo, Habitus e Violência Simbólica, de Pierre Bourdieu. Lembrase que a noção adotada aqui é a que trata de relações humanas.

Considera-se a noção passadista de "designer autor" aquela que o compreende um agente social que constrói objetos e/ou imagens gráficas de modo autoritário, autônomo e individual, sem nenhuma interferência externa. E que essa construção se dá de maneira ininteligível, como se uma força maior e desconhecida tivesse "baixado" em sua mente, tornando-o, assim, um indivíduo especial no meio de trabalhadores ordinários. Tal noção é uma crença - que se considera aqui como carismática - não ponderada sobre outras circunstâncias, como por exemplo a interveniência das questões da estrutura social a qual pertencemos, isto é, o modo de produção capitalista, no qual é o agente de produção, o dono da indústria (e não o designer), quem dita quais os objetos, quantos e como serão produzidos, de forma a procurarem sempre, ao final, a produção do mais-valor. Além disso, é importante ressaltar que, na sociedade industrial, a mercadoria possui menor valor de uso e maior valor de troca simbólica. 
No programa de pós-graduação do Departamento de Artes e Design da PUCRio existe uma praxe que trata da metodologia. Todos os participantes devem explicar o porquê do emprego desse ou daquele método. Daí ao apresentar a escolha julga-se que se deve discuti-la, mesmo sabendo que nesta dissertação não seria o lugar de aprofundar esse debate. Desta forma, tal método tem uma abordagem que busca a eliminação dos erros de uma hipótese no confronto com a própria realidade dos fatos, embora tenha-se a tendência de defender que esse, tal como qualquer outro método, possa ser frágil na determinação disso que é uma hipótese ou disso que nomeamos realidade dos fatos. Supõe-se que nessa ambição de encontrar a verdade, também parta de noções pré-estabelecidas e as considere inquestionáveis. Faz isso a partir da crença ${ }^{6}$ na ideia de que é possível testar a falsidade de uma proposição, ou seja, a partir de uma hipótese, se estabelece uma situação abstrata ou resultado experimental, que nega essa hipótese e daí tenta-se realizar experimentos para negá-la.

A pesquisa terá caráter investigativo e qualitativo, e se aportará de uma pesquisa bibliográfica exploratória para definir o fenômeno da autoria no Campo do Design ao longo do tempo. Esta bibliografia será tanto de escritores do Campo do Design quanto da Filosofia, Sociologia e Semiologia, visto que vários estudiosos que não são do Campo do Design escreveram sobre autoria em diversos outros campos, tais quais o Campo da Arte, Cinema, Literatura etc.

Desta forma, organizou-se o trabalho em quatro partes: $O$ surgimento da noção de autoria, no Capítulo 2; A violência simbólica e o fetichismo da mercadoria: a manutenção do pensamento acrítico no campo do design, no Capítulo 3; Toda escolha estética é uma escolha politica, no Capítulo 4 e Crítica do Design Autoral, no Capítulo 5.

No Capítulo 2 - O surgimento da noção de autoria - procura-se analisar textos tidos como consagrados no Campo da Arte, a fim de compará-los com estudos que se aproximam mais do campo sociológico, muitas vezes tirados do próprio Campo da Arte. Desde já se observa que o Campo do Design "importou" muitos de seus valores e crenças do Campo da Arte. ${ }^{7}$ Examina-se a visão de autoria

\footnotetext{
${ }^{6}$ O termo "crença" aqui é importante, pois é necessário que o pesquisador "acredite" que pode alcançar a verdade, que tal como método é um postulado fixo, sem possuir a dinâmica e complexidade do real.

${ }^{7}$ Julga-se importante lembrar aqui que "Campo" é um termo técnico que advém da teoria social de Pierre Bourdieu, termo este que será analisado no Capítulo 3.
} 
com cunho social, comparando as noções de autor ou artista ao longo dos diversos períodos da história da humanidade até chegar à Idade Moderna, para, assim, compreender de maneira mais clara as transformações e os porquês destas terem ocorrido na História da Arte. Serão mencionados também aspectos sobre o surgimento e implantação da noção do individualismo no sujeito moderno para melhor definir a relação entre tal surgimento e seus valores com o surgimento do autor carismático.

No Capítulo $3-A$ violência simbólica e o fetichismo da mercadoria: a manutenção do pensamento acrítico no campo do design - o texto será apoiado nas noções de Campo, Habitus e Violência Simbólica de Pierre Bourdieu, e na noção de fetichismo da mercadoria, de Marx e Engels. Isso será feito para definir de modo claro e distinto os motivos que levam os agentes de legitimação do Campo do Design a perpetuar tais valores, considerando que o campo é sempre um lugar de luta, onde os dominantes são os ditos agentes que podem legitimar e que os mesmos conservam (no sentido de serem conservadores) o Campo do Design. Para tanto se investigará a influência da Violência Simbólica nas instituições de ensino do Campo do Design e, como dito anteriormente, as noções de Habitus e de Violência Simbólica, nas quais se apoiará para entender porque este conjunto de disposições que rodeiam a noção de design autoral são socialmente construídas. Tais disposições não passam pelo nível consciente de quem age e essas ações socialmente construídas têm a sua parte mais sofisticada naquilo que não nos damos conta. Também será feita uma investigação a respeito da noção de fetichismo da mercadoria no mercado em que os designers atuam, apontando as consequências de tal noção para a manutenção do trabalho alienado, especialmente o trabalho estranhado. Tais relações citadas acima contribuem para a manutenção de um campo acrítico, onde não é questionado para quê ou para quem o designer realiza seus projetos, situando-o em um vazio atemporal.

No Capítulo 4 - Toda escolha estética é uma escolha política - será realizada uma breve análise acerca do "bom gosto", "boa forma" e "boa estética". Será questionado quem são os agentes que legitimam essas configurações e quais as intenções para tanto. Será feito um breve exame sobre a noção da disciplina Estética desde seu surgimento moderno com Baumgarten e como os ideais sobre o "belo" foram cambiando de acordo com o espaço geográfico e o tempo. Será sustentado que a estética é um arbitrário cultural da sociedade burguesa, uma 
disciplina teórica que postulava princípios fixos para a relação entre a arte e o gosto de certa época, mas, depois transformou-se em uma ciência chave para o estudo da forma na arte e nos produtos industriais. Será defendido que a escolha estética é política, ou seja, é regida por fatores sociais extrínsecos à vontade individual de um autor.

Por último, no capítulo 5 - Crítica do Design Autoral - se fará a crítica propriamente dita à autoria no Campo do Design, de forma a apontar e questionar o que é hegemonicamente ensinado nas escolas de design mundo afora, demonstrando o resultado do estudo. A partir da investigação da noção carismática de design autoral, percebe-se que existem interesses externos e internos ao Campo do Design para que o status quo permaneça do modo que está posto na sociedade. Além disso, no sentido de todos os trabalhos serem coletivos (e defender-se-á aqui que o design é sim uma forma de trabalho, e não apenas um “fazer"), aponta-se a impossibilidade de alguma forma de trabalho ser autoral, individual, autônoma e autoritária.

Julga-se importante ressaltar aqui que se segue a linha de pesquisa sugerida pelo professor Alberto Cipiniuk, a qual defende que por muitas vezes os designers, por se comportarem de maneira carismática, como dito acima, vendem algo que não podem entregar, e que "sua força de trabalho não tem o mérito de eficácia que os pares do campo insistem em defender" (CIPINIUK, 2014, p. 44).

O professor indica, ainda, que quando menciona o termo "produção social", está se referindo a uma noção fundada na teoria social de Marx, ou seja, uma noção que explica as ações humanas inseridas em um contexto social em que se produz as práticas e as relações sociais. Ademais, lembra-se aqui que não existem práticas laborais que não sejam coletivas. Este contexto é o modo de produção industrial, ou seja, o capitalismo (CIPINIUK, 2014, p. 80).

Além disso, julga-se importante apresentar os motivos que me ${ }^{8}$ levaram a escolher o presente assunto. Ingressei no curso de design gráfico no ano de 2010 na Universidade Federal de Pelotas que, à época, figurava como a melhor do Estado do Rio Grande do Sul e a terceira mais bem qualificada do país, segundo avaliações do MEC. Esse mérito, segundo alguns especialistas, se dava pelo fato de o curso de

\footnotetext{
${ }^{8}$ Utiliza-se aqui a primeira pessoa do singular, por tratar-se de eventos ocorridos somente na vida do autor.
} 
design estar localizado no mesmo prédio onde funcionava o curso de artes, fazendo, assim, com que os cursos se motivassem internamente e compartilhassem muitas das disciplinas (o primeiro semestre dos dois cursos eram praticamente iguais).

Pessoalmente sempre tive interesse na área e considero que as disciplinas mais interessantes foram as relacionadas à Teoria Crítica, Cultura, Sociologia e Filosofia. Por alguma razão que desconheço, sempre gostei de questionar alguns dogmas hegemônicos, tanto no Campo do Design quanto no Campo da Arte.

Trabalhei por três anos em uma agência de publicidade importante na cidade de Pelotas-RS, onde entrei como estagiário e fiquei nesse local como profissional de design até tornar-me designer sênior. Ao me decepcionar com o mercado e perceber que o trabalho do designer não possui o caráter carismático e autoral que os professores defendiam existir na universidade, resolvi voltar para o meio acadêmico com a finalidade de ampliar meus conhecimentos e questionar tais características que hoje sei que são inverossímeis.

Para tanto ingressei - na condição de aluno especial - no Programa de PósGraduação do Centro de Artes da UFPel, cursando a disciplina intitulada de "Design de Autor", ministrada pela Professora Lúcia Bergamaschi Costa Weymar. Lá pude me deparar, por meio de textos teóricos de filósofos e sociólogos - tais como Michael Foucault e Roland Barthes -, com uma questão que se tornou muito cara para mim: a autoria no Campo do Design.

Com o intuito de aprofundar meus estudos na questão autoral no Campo do Design, procurei saber quem também questionava a episteme de tal assunto, e por meio de conhecidos descobri os escritos do professor Alberto Cipiniuk, que há muito se debruça nas diversas teorias do design, dentre elas a questão da autoria. Foi por meio da leitura de seu livro "Design: o livro dos porquês", que comecei a enxergar os porquês de toda a abordagem carismática, uma orientação idealista, que tanto havia lido e nunca entendido, estar ultrapassada. 


\section{O SURGIMENTO DA NOÇÃO DE AUTORIA}

Inicia-se este estudo pela definição do que é considerado como surgimento da autoria primeiramente no Campo da Arte, pois se percebe que o Campo do Design tomou tais características "emprestadas". O que se tem como hegemônico advém deste "empréstimo". Depois se aproximará do que se julga ser o nível da sua verdadeira natureza, ou seja, a demonstração de que a noção do surgimento (a hegemônica) é relativamente recente, romantizada e carismática. Os motivos ficarão evidentes a seguir.

\subsection{Uma brevíssima história da autoria no Campo da Arte}

Julga-se imprescindível estudar o passado - a história - da autoria no Campo da Arte, pois defende-se que o Campo da Arte e o Campo do Design possuem fronteiras porosas, ou seja, muitos dos valores que se têm no Campo do Design foram apropriados ou absorvidos do Campo da Arte.

Sustenta-se que a prática profissional do designer possui uma história que tem sua gênese na prática dos oficiais mecânicos da Idade Média, que, com o início da Idade Moderna, se constituíram nos artistas. Ao se institucionalizarem pode-se afirmar a sua origem no Campo da Arte, pois com a organização da sociedade, depois do sistema feudal, em uma nova forma de produção (o capitalismo), o artista perdeu sua antiga forma de patrocínio, o mecenato. $\mathrm{O}$ antigo sistema que oferecia sustentação à prática da arte, assim como para todas as outras formas de trabalho, foi substituído pelo sistema crítico-comerciante, foi privatizado. Tal substituição acabou por deixar o artista em uma posição precária neste novo modo de produção, em que todas as formas de trabalho acabaram por integrar o sistema capitalista. Assim, esses profissionais foram adotando novas posições para venderem suas forças de trabalho no mercado de trabalho capitalista como artistas gráficos que trabalhavam para a indústria, tal como ilustradores, artistas de publicidade etc. (WOLFF, 1982, p. 25). 
Um exemplo que ilustra bem tal migração foi o do modelo de trabalho empregado por Wedgwood na sua fábrica de cerâmica, a Etrúria, na segunda metade do século XVIII. Ao perceber que seus modeladores (artífices habilidosos) não compreendiam os princípios do Neoclassicismo (estilo que estava na moda à época, por conta das novas descobertas arqueológicas no sul da Itália), Wedgwood contratou artistas, supondo que estes, por estarem na Academia, teriam seus trabalhos mais valorizados pelos clientes (FORTY, 2007). Aqui percebe-se que além dos motivos estéticos, Wedgwood se valeu da "aura" que cerca a atividade artística para a fabricação de peças de louça em série. Empregando a antiga noção da autenticidade e unicidade da criação artística, justamente pela ideia de autoria, deu legitimidade aos objetos industriais que produzia em série.

Assim, julga-se importante fazer um apanhado histórico para compreendermos como e de onde surgiram as noções que colocam o artista como um "gênio inventivo", dotado de habilidades "sobre-humanas", agraciados por uma força divina.

Conforme indicamos no início deste capítulo, não se pretende aqui fazer um longo e detalhado estudo sobre a História da Arte, mas é importante compreender que "as origens da arte coincidem com as do próprio homem" (OSINSKI, 2002, p. 11), posto que se sustenta que isso que hoje chamamos de arte é, na verdade manufatura, algo realizado por uma prática laborativa como outra qualquer. Isto posto, é importante ressaltar também que o significado ou sentido do termo Arte é situado no tempo e no espaço, assim ele muda ao longo das eras e conforme o lugar, mas estudar tais conceitos também não é o pretendido no presente capítulo. O que se busca aqui é compreender como se deu a criação da noção de artista como criador individual, autônomo e autoritário, que deu origem à mesma noção no Campo do Design.

Segundo Osinski (2002), do Paleolítico até o Renascimento, os conhecimentos que hoje denominamos artísticos eram transmitidos através da tradição. Na pré-história, o equivalente a isso que hoje chamamos de artista era considerado um feiticeiro, pois tinha o poder de materializar as coisas do além em imagens e, muito provavelmente, não se diferenciava esse profissional de um curandeiro, sacerdote ou mágico, e ainda hoje é possível notar tais características em povos como os esquimós, aborígenes australianos, ameríndios e alguns grupos 
africanos. Tais personalidades dotadas de poderes sobre-humanos, que são chamadas por nós hoje de xamãs, tinham um lugar de destaque em seu meio social, pois possuíam um status que lhe proporcionava privilégios, tais quais isenções parciais das suas obrigações cotidianas (OSINSKI, 2002, p. 12).

Com o advento das técnicas de agricultura e pecuária e com a consequente sedentarização do homem, no período Neolítico, fez com que aquilo que hoje chamamos de produtos de arte obtivessem características mais utilitárias. Assim, o artista teve sua importância diminuída dentro da comunidade, sendo tratado como qualquer outro tipo de artesão (Idem., Ibidem.). As atividades que necessitavam de força, do uso das mãos, passaram a ser vistas como atividades pouco honrosas, ligadas ao trabalho servil ou escravo, incompatível com a posição social dos homens livres (Idem., p. 13).

Com o processo de urbanização das cidades e com o surgimento da civilização agrícola, que ocorreu ao fim do período Neolítico, surgiram as cidadesestados, o que fez por centralizar a administração e crescer a divisão do trabalho. Com a subsequente instituição da escravidão no mundo antigo, qualquer tipo de trabalho manual sofreu uma depreciação, e o trabalho disso que hoje chamamos de arte se incluía nesta depreciação. Assim sendo, por conta do desprezo pelo trabalho manual, visto como atividade pouco digna de consideração, os monumentos de arte eram realizados por escravos e estes, logicamente, foram destinados ao anonimato. Percebe-se aqui talvez uma primeira fase de anonimato na vida artística. Segundo Hauser, "o mundo antigo venera a criação, mas despreza o criador" (HAUSER, apud. OSINSKI, 2002, p. 15).

$\mathrm{Na}$ cultura greco-romana, o artista atingiu um status um pouco mais elevado do que em outras culturas do mundo antigo, porém não tinham o mesmo prestígio que filósofos e poetas, tal como hoje se afirma. "O anonimato já não é uma regra, tendo chegado até nós não só os seus nomes, mas também informações sobre suas vidas" (OSINSKI, 2002, p. 17). Segundo a autora, neste período já encontramos obras assinadas que datam de aproximadamente 700 a. C., época em que surge a figura do artista, isto é, do profissional habilitado naquela arte (do grego tekhné, traduzido para ars no latim), como personalidade individual. Neste período temos exemplos como Miron, Policleto e Fídias, que foram referenciados e criticados por escritores da época. Isso mostra que esse profissional passou a ser valorizado de uma maneira diferente dentro daquela sociedade (Idem., Ibidem.). 
Com a queda do Império Romano as cidades foram desestruturadas, tendo por consequência a concentração da vida no campo. A crença pagã foi repudiada, pois contrariava os princípios cristãos e, assim sendo, a produção artística sofreu importante queda na qualidade e na quantidade, "situação essa que acabou durando alguns séculos" (OSINSKI, 2002, p. 18).

Com o predomínio da Igreja sobre as instituições seculares na Idade Média, a produção da arte passou a se concentrar nos mosteiros. Quem detinha o monopólio do conhecimento de todos os saberes, incluindo o da arte, eram as ordens monásticas, e dominavam toda a produção do trabalho que hoje denominamos artístico. Desta maneira surgiu o espírito comunitário da produção artística entre os monges, e dentro dos mosteiros não era permitido o surgimento de individualidades, "predominando o silêncio discreto do anonimato" (Idem., p. 19). De modo que esses profissionais ou artistas continuavam a ser vistos como meros artesãos, que tinham a função de atender a demanda quase exclusiva das instituições religiosas (Idem, p. 20).

A partir da Regula de São Bento (mais precisamente a partir da regra LVII De artificibus monasterii) sabe-se que os monges podiam exercer as Artes, contanto que com a permissão do abade e sem envaidecer-se de modo algum, mesmo atingindo os mais impressionantes resultados, porque cada produto servia para a glorificação de Deus. "Inútil dizer que a avidez pelo dinheiro era ainda mais condenada" (RUGIU, 1998, p. 26).

Desse modo, surgiu a afirmação do poder da Igreja e, com isto, a necessidade de construir magníficas e monumentais catedrais, de modo a enaltecer tal poder e onde aqueles que nelas trabalhavam eram solenemente ignorados. Dos ateliês monásticos surgiram as loggias (corporações, irmandades ou confrarias) dos pedreiros, que eram cooperativas de artesãos, formadas com a finalidade de construir tais monumentos. Tais loggias eram organizações que operavam de forma coletiva, nas quais ninguém era livre, nem o administrador nem o arquiteto. Todos tinham que trabalhar de acordo com um plano pré-concebido e traçado pelas autoridades eclesiásticas (HAUSER apud. OSINSKI, 2002, p. 21).

Antes do surgimento dos burgos, por volta dos séculos XI e XII, ainda não havia um nome para isso que chamamos de trabalho artístico ou para qualquer outro tipo de atividade laboral. "As palavras que mais se aproximavam (labor, opus) colocavam o acento principalmente na fadiga física e moral" (SCHIMITT apud. 
RUGIU, 1988, p. 29). Até este momento, o trabalho (tanto artístico como qualquer outro, lembrando que não havia diferenciação entre o trabalho artístico e outro qualquer) expressava a ideologia feudal, como uma espécie de forma de penitência relacionada ao pecado original (RUGIO, 1988). Mas com o surgimento da burguesia, entre os séculos XI e XII, e com o aparecimento do poder de compra, surgem os indivíduos privados, que formaram um mercado para o consumo de objetos, mais bem elaborados e que davam prestígio e distinção para aqueles que os possuíssem e que hoje chamamos de objetos de arte. Assim, gradativamente, os artistas foram se emancipando das antigas noções teológicas e morais e se estabelecendo como mestres independentes. Tal passagem, que ocorreu por volta do século XIV, fez com que os artistas se organizassem para proteger o seu mercado de trabalho surgindo, assim, as guildas ou corporações de ofício (OSINSKI, 2002). "Nas oficinas individuais [...] que compunham uma guilda, os mestres artesãos tinham liberdade não só de dispor de seu tempo, mas também de escolher os meios artísticos" (HAUSER apud. OSINSKI, 2002, p. 21). Aqui o anonimato continuava a predominar, e o sistema via isso que chamamos hoje de artista apenas como um “trabalhador habilidoso" (OSINSKI, 2002, p. 22).

Mas, no século XV, quando "as velhas muralhas das cidades comunais sobrevivem só como vestígio arquitetônico" (RUGIO, 1998, p. 88), as corporações começaram a se desfazer, pois surgiu um novo tipo de clientela que consumia objetos agora distintos e prestigiosos (obras de arte), consequência do enriquecimento das cidades e fortalecimento da burguesia. De modo a facilitar o consumo de mercadorias, pessoas como Cosimo de Medici criaram redes bancárias, "responsáveis pelo impulso inicial do sistema capitalista" (OSINSKI, 2002, p. 25), criando o sistema que associava os artistas com os mecenas. Assim sendo, o título de mestre de Arte, no qual o artista tinha que passar por muitos anos de tirocínio até conseguir o grau de mestre, torna-se secundário, com o advento do Renascimento, surgindo apreço pelo valor individual, acreditando na figura multidisciplinar do artista, que constrói pontes, pinta, cria armas de guerra entre muitas outras coisas meritórias para aquele período histórico. Importante citar aqui a existência de Leonardo, que pretendia criar obras hidrográficas, um cavalo de bronze monumental, objetos voadores etc. Leonardo também firmou residência nas cidades de Veneza e Milão, ambas na Itália, e, ao final da vida, em Amboise, na França 
(KING, 2018), mostrando, assim, que os muros que abrigavam as corporações de ofício haviam caído, pelo menos metaforicamente.

Surge, então, a separação entre o artista e o artesão, que não havia diferenciação antes do século XV. "Os dotes do indivíduo sobressaem sobretudo, é óbvio, na invenção estética e muito menos no bater ferro ou no serrar tábuas: uma razão a mais para acentuar a separação entre artistas e artesãos" (RUGIO, 1998, p. 90).

Com a queda da hegemonia das Corporações, surgiram as oficinas de artistas, e isto fez com que o artista absorvesse mais uma função laboral: a de tratar pessoalmente com seus clientes. "Este tratar pessoalmente com o cliente retroage no perfil do artista e, portanto, na sua formação: todo cliente encomenda para si e segundo os próprios desejos e as próprias exigências" (Idem., p. 91). Assim, o artista teve que aprender a agir com destreza para com seus clientes, de forma a escutar e orientá-lo, que possuía "preferências subjetivas, de conteúdo e de estilo, às vezes de vanguarda e outras vezes tradicionais, até mesmo nostálgicas, e frequentemente com pouca clareza e determinação" (Idem., p. 92). Dessa maneira, após a institucionalização da arte e do artista, surge o caráter empreendedor do artista, que também é agora vendedor de si mesmo e dos seus produtos. Interessante como este parágrafo, mesmo que circunscrito no século $\mathrm{XV}$, nos lembre das aulas de marketing que são ensinadas nas escolas de design em pleno século XXI.

Neste período surge a ideia de gênio artístico, "um ser notadamente individual, dotado de um dom divino e com força criativa inata" (OSINSKI, 2002, p. 29). Esta definição é precisamente a noção que se pretende criticar na presente dissertação, visto que é essa a noção que se supõe ser aceita, reproduzida e ampliada pelos agentes de legitimação do Campo do Design.

\subsection{O Sujeito, sujeito de si mesmo.}

Com o advento da Revolução Industrial, a mecanização e a subsequente divisão do trabalho, surge o sujeito individualizado em razão desse conjunto de fatores. Ao alugar sua força de trabalho em uma atividade especializada para o lucro do patrão, esse revolucionário modo de produção terminou por criar inadvertidamente a noção do trabalhador livre, diferentemente dos meios de produção comunitários existentes nas comunidades pré-capitalistas. Mas é preciso 
ponderar que essa liberdade é radicalmente ambígua. É principalmente uma liberdade negativa, pois ao atingi-la o sujeito social perde uma porção de apoios, de meios de sustentação. Desta forma, acaba que cada indivíduo se esforça, de maneira isolada, em buscar o seu sustento, tornando a sociedade cada vez mais "atomizada", ou seja, ao invés do modo de produção capitalista construir comunidades produtivas integradas, percebemos a existência de indivíduos "livres" produzindo ou vendendo sua força de trabalho para iniciativas privadas. "Esse indivíduo livre é um desamparado em sua sociedade" (FIGUEIREDO, 1993, p. 45),

Segundo Figueiredo (1993), existem certas precondições para o surgimento da psicologia como ciência no século XIX, tais quais a experiência da subjetividade privatizada, a constituição e desdobramentos da noção de subjetividade na Modernidade, a crise da Modernidade e da subjetividade moderna em algumas de suas expressões filosóficas, o sistema mercantil e individualização e a crise da subjetividade privatizada ou decepção necessária.

No presente subcapítulo se procura definir de modo claro os motivos do surgimento das noções de subjetividade e individualidade para desenvolver a influência de tais noções nas ideias carismáticas e românticas que rodeiam o sujeito enquanto autor individual. É dizer, parece ser claro que tais concepções formaram ou reforçaram as noções idealistas que permeiam os campos da criação, nas quais o indivíduo se coloca como criador absoluto de "obras", quando estão, na verdade, reproduzindo o que os produtores ensejam, em que muito pouco ou nada estão a criar per se.

Segundo o autor, existe uma falsa sensação de que nossos sentimentos e pensamentos são originais, ou seja, é comum pensarmos que o que estamos vivendo hoje nunca foi vivido por mais ninguém, que somos totalmente originais. Mas as pesquisas de historiadores e antropólogos nos mostram que esse modo de pensar e sentir não são universais. Que essa experiência, a de sermos sujeitos possuidores de tomada de decisões, sentimentos e emoções privadas só surgem em uma sociedade com determinadas características (FIGUEIREDO, 1993).

Nessas épocas, as artes e a literatura revelam a existência de homens mais solitários e indecisos do que em épocas nas quais dominam as velhas tradições e não existem graves conflitos. Quando há uma desagregação das velhas tradições e uma proliferação de novas alternativas, cada homem se vê obrigado a recorrer com maior constância no seu "foro íntimo" - aos seus 
sentimentos (que nem sempre condizem com o sentimento geral), aos seus critérios do que é certo e do que é errado (e na sociedade em crise há vários critérios disponíveis, mas incompatíveis). A perda de referências coletivas, como a religião, a "raça", o "povo", a família ou uma lei confiável obriga o homem a construir referências internas. Surge um espaço para a experiência da subjetividade privatizada: quem sou eu, como sinto, o que desejo, o que considero adequado? (FIGUEIREDO, 1993, p. 21)

Tal busca pelo "foro íntimo" é o objeto de análise no presente capítulo: o homem procurando expressar de forma individual aquilo que ele sente, como se isso fosse algo único e inédito, não considerando que esta procura é consequência, como dito acima, da imersão em uma sociedade com características determinadas. A sociedade estudada aqui é a Moderna, ou seja, regida pelo modo de produção industrial, o capitalismo, que tem por finalidade a produção de mais-valor.

Figueiredo (1993) afirma que ao longo dos últimos séculos as experiências da chamada subjetividade privatizada se tornaram determinantes da consciência que o homem possui de sua própria existência. Antes da Idade Moderna eram poucos os elementos de uma sociedade que podiam ter liberdade para se reconhecerem como seres autônomos e capazes de iniciativas e desejos próprios. Reflete que hoje essa noção se tornou a imagem generalizada que temos de nós mesmos, e que muitos se sentem incomodados quando essa crença é colocada em dúvida: "resistimos à ideia de que não tenhamos controle sobre nossas vidas" (Idem., p. 23).

Essa busca por controle parece em muito se relacionar com a idealização do homem enquanto indivíduo autônomo. Nota-se que, como dito anteriormente, nem sempre foi assim: no período medieval, por exemplo, o homem se sentia parte de uma ordem superior, na qual havia uma figura de autoridade. Essa figura era Deus e ela descia verticalmente pelos quadros dirigentes da igreja e alcançava os regimes políticos temporais, chegando finalmente ao indivíduo. Mas, com a chegada do Renascimento, o homem foi colocado no centro do mundo (Antropocentrismo), e se viu obrigado a "escolher seus caminhos e arcar com as consequências de suas opções” (Idem., p. 25), porém essa escolha não era tão livre assim, mas dirigida por mecanismos sociais muito sutis e que a maioria das pessoas não tinha meios de percebê-los. É claro que a crença em Deus não desapareceu, não é assim que os processos históricos se dão, mas o que aconteceu foi que Ele se distanciou. Assim, 
segundo o autor, o mundo começou a ser visto como objeto de uso a serviço dos homens (Idem., p. 26).

Outro momento histórico interessante para dar força à argumentação foi o do Iluminismo, mais precisamente à sua crítica, o Romantismo. Um pouco antes, em uma sociedade que passava por uma série de mudanças, tem-se como um dos marcos do início do período moderno o pensamento de Descartes, tido como fundador do racionalismo moderno (mais adiante se demonstrará que esse processo - o da construção do período moderno - foi longo e teve várias etapas até constituirse concretamente). Logo depois, o Romantismo critica a ideia cartesiana, pois não vê o homem como um ser racional, pensante, mas sim como um ser passional e sensível. O Romantismo surge como um movimento essencial na crise do sujeito moderno, pois destrona o "eu" antropocêntrico de seu lugar de senhor soberano. Ademais, surge uma noção de que o homem é um ser com níveis de profundidade que ele mesmo desconhece. Mas existe aqui um paradoxo, que é a valorização da individualidade e da intimidade. A ideia de "gênio" expressa bem tal valorização, pois seria ele um indivíduo especial por natureza, dotado de um dom singular, e que tem a obrigação de realizá-lo. Porém, por outro lado, este indivíduo encontra em si grande indisposição e dificuldade em sua vida prática, pois ele está crente que essa é sua missão, pois trata-se de um desígnio divino. Fica claro que, quando pensamos no alto grau de individualismo e solidão presente no século $\mathrm{XX}$, este pensamento é indissociável da presença em nós do sujeito romântico (FIGUEIREDO, 1993).

O surgimento romântico da concepção de "gênio" corroborou para o surgimento de uma gama de artistas que eram encarados pela sociedade (e muitas vezes por si mesmos) como seres especiais, dotados de um dom que, quase a totalidade das vezes, era associado ao divino. Essas ideias permanecem até hoje e ajudam a legitimar o criador como autor, que é aqui o objeto de análise crítica. Porém, embora o Romantismo como movimento artístico tenha durado pouco, suas teses permanecem indeléveis nos dias de hoje. A crescente industrialização trouxe outros desafios para a sociedade, e não havia espaço no chão da fábrica para empregar uma força de trabalho "genial". Forty (2007) relata um exemplo que torna isso muito claro, que é o já citado dono da Etrúria, fábrica de cerâmica, Josiah Wedgwood, que buscava “fazer de seus homens, máquinas” (FORTY, 2007, p. 48).

Assim, cresce a indústria que se baseia na produção padronizada (sem espaço para idiossincrasias pelas mãos dos trabalhadores) e surge o grande consumo 
massificado de produtos industriais estandardizados. Aqui Figueiredo (1993) questiona "onde ficava, então, aquela ideia de que um é único e diferente dos demais?" (FIGUEIREDO, 1993, p. 50). Crê-se aqui que essa diferenciação e unicidade são pensamentos de grande relevância para surgir a noção carismática de autoria, pois quando os homens vivenciam as experiências de uma subjetividade privatizada (e percebem, assim, que não são tão livres e únicos quanto imaginavam) eles ficam perplexos. Pensam sobre os motivos e os significados de tudo que fazem, sentem e pensam sobre eles mesmos (Idem., Ibidem.).

Numa sociedade em que o homem se coloca, egoisticamente, como indivíduo uno, separado dos demais, surge também a necessidade do Estado em controlá-los. Por consequência torna-se interessante para o Estado que surjam figuras ditas "autorais", de modo a produzirem o que os produtores decretam, acreditando ou fingindo acreditar que seus projetos são inovadores e criativos ajudando, assim, para o aumento massivo do consumo social de objetos frívolos. Tudo isso gera uma incerteza quanto às liberdades e singularidades do indivíduo, que ajuda aqui a melhor entender e colaborar com o processo de desconstrução do sujeito enquanto autor individual.

\section{3. $O$ ato social é sempre um ato coletivo.}

Há muito debate-se a questão da autoria individual nos diversos gêneros de expressão do Campo da Arte. Existe, como se viu acima, a noção de que o criador teria uma espécie de domínio sobre sua "obra", e esta noção é tida frequentemente como uma verdade absoluta. Defende-se aqui que tais noções se baseiam em crenças, e não em fatos históricos e/ou científicos.

Uma dificuldade que se encontra para ter-se uma boa compreensão dos diversos gêneros de expressão do Campos da Arte é o estudo da história de determinado campo se basear na figura do artista, e não na da arte em si, seja ela a literatura, a pintura, o cinema etc. "Na História da pintura [...] um dos maiores obstáculos ao bom entendimento e análise da arte tem sido a visão da história da arte como a história dos artistas" (WOLFF, 1982, p. 132). Barthes (2004) retrata tal questão de forma incorrigível, ao falar de autores "gênios" como Baudelaire, Van Gogh e Tchaikovski: 
O autor reina ainda nos manuais de história literária, nas biografias de escritores, nas entrevistas das revistas, e na própria consciência dos literatos, preocupados em juntar, graças ao seu diário íntimo, a sua pessoa e a sua obra; a imagem da literatura que podemos encontrar na cultura corrente é tiranicamente centrada no autor, na sua pessoa, na sua história, nos seus gostos, nas suas paixões; a crítica consiste ainda, a maior parte das vezes, em dizer que a obra de Baudelaire é o falhanço do homem Baudelaire, que a de Van Gogh é a sua loucura, a de Tchaikovsky o seu vício: a explicação da obra é sempre procurada do lado de quem a produziu, como se, através da alegoria mais ou menos transparente da ficção, fosse sempre afinal a voz de uma só e mesma pessoa, o autor, que nos entregasse a sua 'confidência'. (BARTHES, 2004, p. 57)

Esse erro historicista aparece também no Campo do Design. Assim como Barthes na Literatura e Janet Wolff no Campo da Arte, Forty (2007) também percebe tal equívoco se repetir no Campo do Design. Nota-se que a fronteira já préexistente entre o Campo do Design e o Campo da Arte se torna cada vez mais porosa, uma vez que os meios de propagação midiáticos tratam a profissão com tamanha irresponsabilidade, prestando um desfavor aos estudiosos e pesquisadores que buscam justamente caracterizar que tipo de trabalho é o do designer. Forty (2007) já havia questionado este modelo no qual designers contam a história de seus designs, e acredita-se que é exatamente isto que ocorre nas diversas mídias, tais quais livros (didáticos ou não), filmes e documentários que colocam o designer como centralizador de ideias e projetos. Os designers costumam falar e escrever apenas sobre o que eles fazem. Desta maneira o design passou a ser visto como algo pertencente ao domínio total e único do designer. Tem-se como consequência mais grave, a ampla reprodução por meio do ensino de tais noções individualistas nas escolas de design, "onde os estudantes correm o risco de adquirir ilusões grandiosas sobre a natureza de seu trabalho e ficar frustrados em suas carreiras subsequentes" (FORTY, 2007, p. 325).

O que Forty (2007) acusava acontecer nos livros de design está se repetindo em muitas outras mídias. Forty defende que, para muitos designers, a solução de problemas não está na teoria que se aprende nas escolas e na profissão em si, mas sim no engodo com o mito da própria onipotência e na importância máxima de seu papel de agentes da ideologia burguesa. "É mais comum escutá-los (aos designers) descrever seu trabalho como se tivessem total poder sobre ele" (Idem., p. 325).

Barthes (apud WOLFF, 1982) argumenta, como sugerido no capítulo anterior, que o autor surge no período moderno, criado pela sociedade, tal como 
criou a pessoa humana (o indivíduo). Para ele, "um texto não é uma linha de palavras que liberam um significado 'teológico' único (a 'mensagem' do AutorDeus), mas um espaço multidimensional no qual vários escritos, nenhum deles original, se fundem e se chocam" (BARTHES apud. WOLFF, 1982, p. 132). Barthes (2004) é categórico ao analisar a obra de Balzac, a novela Sarrasine:

$\mathrm{Na}$ sua novela Sarrasine, Balzac, falando de um castrado disfarçado de mulher, escreve esta frase: "Era a mulher, com os seus medos súbitos, os seus caprichos sem razão, as suas perturbações instintivas, as suas audácias sem causa, as suas bravatas e a sua deliciosa delicadeza de sentimentos." Quem fala assim? Será o herói da novela, interessado em ignorar o castrado que se esconde sob a mulher? Será o indivíduo Balzac, provido pela sua experiência pessoal de uma filosofia da mulher? Será o autor Balzac, professando ideias 'literárias' sobre a feminilidade? Será a sabedoria universal? A psicologia romântica? Será para sempre impossível sabê-lo, pela boa razão de que a escrita é destruição de toda a voz, de toda a origem. A escrita é esse neutro, esse compósito, esse obliquo para onde foge o nosso sujeito, o preto-e-branco aonde vem perder-se toda a identidade, a começar precisamente pela do corpo que escreve. (BARTHES, 2004, p. 57)

Esses escritos que se fundem e se chocam, como citado por Barthes (2004), é o que corrobora aqui a pensar que toda a arte é produzida coletivamente, mesmo quando a produção é tida como "mais individual", como é o caso da pintura ou da poesia, por exemplo. Mas essas individualidades dependem de toda uma estrutura já pré-concebida, e é isso que muitos dos pares da profissão (que são agentes de legitimação) não enxergam ou se recusam a enxergar. "O ato individual de criação é evidentemente um ato social" (WOLFF, 1982, p. 133). Todo o ato social é, por natureza, um ato coletivo.

Existe, também, a ideia romântica do artista como gênio (conforme citado no capítulo anterior) que, segundo Hauser (1982) foi elemento novo na concepção da arte renascentista (apesar de a Escola Romântica ter sido criada de fato quase duzentos anos depois). A obra de arte seria uma criação de um agente autocrático que transcende as tradições, teorias e regras. A noção de gênio é aquela que coloca o indivíduo como alguém que recebe um dom divino, e que esta força criadora inata é exclusivamente individual (HAUSER, 1982, p. 432). Mas acontece que o artista/autor nunca cria algo individualmente, e esta noção apenas "obscurece o fato de que a arte continua a ser um produto coletivo" (WOLFF, 1982, p. 41). E isto também se dá no Campo do Design que importou muitos de seus valores e fundamentos teóricos do Campo da Arte. 
Becker (2010) ressalta que na arte, assim como em todas as formas de trabalho, o que existe são atividades coletivas. Para Becker (2010), todo o trabalho artístico envolve a atividade conjugada de um determinado número de pessoas, e estas pessoas não são apenas aquelas diretamente envolvidas com a criação da obra per se, mas também fabricantes e distribuidores tornam-se figuras importantíssimas para a realização de tais obras. O fabrico e a distribuição de materiais, assim como o equipamento necessário à maioria das atividades artísticas são atividades fundamentais para a manufatura de trabalhos de arte, e aí é inerente que fabricantes de instrumentos musicais, de tintas e de telas, das sapatilhas e roupas de bailarinos, das câmeras fotográficas têm de ser disponibilizados para os indivíduos que produzem os trabalhos de arte (BECKER, 2010, p. 29).

Para ele, uma vez realizada a obra, é necessário que alguém lhe seja sensível, afetiva ou intelectualmente. Logo a obra de arte também "não ocorre sem a presença de um público que reaja e aprecie" (Idem., p. 29). O "mundo da arte" de Becker envolve uma cadeia ainda maior em nossa sociedade, pois pintores dependem de fabricantes de molduras, de tintas e de pinceis. Além das ferramentas materiais dependem também dos galeristas, colecionadores e conservadores de museus para garantirem o espaço de exposição de seus trabalhos e, consequentemente, de seu apoio financeiro. Eles vão depender também de seus críticos e historiadores de arte para justificar a própria existência dos seus trabalhos. Dependem, ainda, do Estado para ajudas materiais (subsídios) e também das leis fiscais, de modo a encorajarem os colecionadores a adquirirem seus trabalhos. Também dependem do próprio público pelas respostas emocionais às suas obras e, por último, dependem dos outros artistas que instauram a tradição (ou convenções estéticas, como veremos mais adiante) pela qual suas obras adquirem significado (Idem., p. 37).

Ele ainda questiona se o artista que passa por ter realizado uma obra realizoua de fato ele próprio. Será que alguém pode modificar ou retocar uma obra original de tal modo que aquilo que nos é apresentado já não corresponde exatamente ao que o artista realmente desejava ou criou? Afirma que a reputação do artista e da obra se reforçam mutuamente. Quando a distribuição da arte implica uma transação no mercado, o nível de reputação pode ser convertido em valor financeiro. Isto implica que a decisão de retirar a autoria de uma obra a um artista ou designer famoso e admirado faz com que ela perca totalmente o seu valor. 


\section{Conclusão do Capítulo 2}

Em muitos exemplos, tanto nos dias de hoje como em tempos passados mais ou menos recentes, mostra-se a figura do designer muito parecida como a de um artista: designers ganhando notoriedade nas diversas mídias assim como artistas famosos estão acostumados a receber. Parece ser que esta antiga noção, que há muito poderia ter sido desfuncionalizada, ainda permeia o Campo do Design, confundindo e amargurando muitos profissionais que buscam tal notoriedade.

Forty (2007) esclarece tal ponto logo no início de seu livro que, lembra-se, foi publicado em meados de 1986, há mais de trinta anos. Para Forty (2007), a distinção crucial é que o que denominamos de "obras de arte" são em geral concebidas por (ou sob direção de) uma pessoa, o artista. Isso não é verdade quando se fala de bens manufaturados: a concepção e a fabricação de sua obra permitem aos artistas alguma autonomia, o que levou à crença comum de que uma das principais funções da arte é dar livre expressão à criatividade e à imaginação e, segundo o autor, tal visão certamente não é verdadeira para o design (FORTY, 2007). Ainda assim, nota-se que a visão do designer como um "quase artista" é profundamente ensinada em nossos meios acadêmicos, seja no Brasil, seja no mundo.

Tem-se como primeiros passos a definição de uma preocupação por parte dos profissionais do Campo do Design, quando possuem consciência social, alegam que não possuem uma identidade profissional. Como os pares do campo hegemonicamente relutam em defini-la de modo inteligível, essa identidade foi apropriada do Campo da Arte. Assim, a fronteira do Campo do Design com o Campo da Arte parece ser, por vezes, porosa, flexível, permeável, de modo que muitas vezes não se tem a clareza se estamos falando de arte ou de design.

É notório, desde o paradigma que alguns autores consideram como vigente, qual seja o período histórico que muitos chamam de pós-modernismo, que surgiram muitos designers que possuem a pretensão de se julgarem ou serem julgados pelo Campo do Design e/ou pelo imaginário popular como designers "autores". Mas seriam os produtos criados por eles (na grande maioria das vezes produtos de luxo) trabalhos de design de fato? Defende-se que não. Estuda-se com frequência na graduação da profissão nomes populares de indivíduos que, individual e 
autonomicamente, teriam mudado os padrões do design para sempre. Dificilmente encontra-se alunos formados em design que nunca tenham ouvido falar de nomes como David Carson, o "reinventor" do design editorial (que não se formou em uma escola de design), ou de Philippe Starck e seus diversos produtos de luxo, inclusive assinando a decoração de interiores de hotéis, como o Le Meurice em Paris, França.

O “design" experimental chamava atenção para si, e o inevitável resultado era colocar seus criadores no centro das atenções. Desde os primórdios da arte comercial, sempre houve um punhado de "designers" que se tornaram "estrelas" da profissão, tendo suas obras aclamadas por revistas especializadas, exposições e até mesmo em monografias. (POYNOR, 2010, p. 119)

Segundo Poynor (2010) foi nos anos de 1980 que o senso de auto importância no Campo do Design crescia, e crescia também sua fascinação consigo mesmo (a dos designers). "Houve um aumento significativo na quantidade de palestras informais com designers e de conferências com a participação do mesmo grupo itinerante de figurões do design internacional" (Idem., Ibidem.). Nota-se aqui a insegurança por parte dos profissionais e também o surgimento de monopólios criados pelos ditos "figurões". Tais monopólios surgiram em todas as esferas sociais uma vez que o modelo econômico vigente - o capitalismo industrial ou produtivo - entrou em colapso. 


\section{A VIOLÊNCIA SIMBÓLICA E O FETICHISMO DA MERCADORIA: A MANUTENÇÃO DO PENSAMENTO ACRÍTICO NO CAMPO DO DESIGN.}

O presente capítulo tem por objetivo fazer um breve relato circunstanciado sobre a legitimação da ideologia mercantil e tecnicista em vigor no entorno do Campo do Design, ou seja, a base material na qual essas disposições se realizam e em que os agentes operam. Tal ideologia é utilizada hegemonicamente pelos pares do campo tanto nos estudos e pesquisas que acontecem no âmbito acadêmico quanto no meio das práticas profissionais dos designers. A hipótese central com base no fundamento de que o uso dessa ideologia comercial - que serve como estratégia de manutenção do status quo classista burguês - em nada contribui para o pensamento crítico, crucial para a construção de uma sociedade mais igualitária e para o desenvolvimento da prática profissional do designer. O pretendido no presente capítulo é definir as razões dessa ideologia ser reproduzida no campo e ter contribuído para uma formação de profissionais de design que é identificada aqui como ultrapassada, sejam eles pares do meio acadêmico, sejam agentes do mercado de trabalho. Ademais, se propõe questionar os motivos que levaram esses profissionais despolitizados ou desideologizados a se comportarem apenas como reprodutores técnicos e, ao mesmo tempo, defenderem temas tradicionais do Campo da Arte, tal como o dom, ou talento inato da criatividade. Para tanto, será feita uma resenha calcada em fontes bibliográficas sobre as teorias sociais que estudam os conceitos de fetichismo da mercadoria em Marx e Engels e de Violência Simbólica em Bourdieu. Também será abordada uma conferência crítica de autores que já escreveram sobre o tema no que diz respeito ao Campo do Design.

\subsection{O Campo do Design: um esporte de combate}

Tanto no Campo Universitário ${ }^{9}$ quanto no meio profissional do design, pode-

\footnotetext{
${ }^{9}$ Aqui de acordo com Pierre Bourdieu: "Espaço social específico onde se trava uma luta encarniçada para estabelecer o monopólio legítimo da verdade acadêmica ou universitária, espaço esse marcado
} 
se perceber a recorrência da utilização de termos originados em ideologias comerciais típicas do modo de produção capitalista nas práticas e teorias do design. Atualmente, tanto nos cursos de graduação - que recrutam e preparam os alunos para atuar no mercado de trabalho -, quanto nos cursos de pós-graduação - que recrutam e preparam pesquisadores para teorizar sobre nossa prática profissional utiliza-se uma bibliografia predominantemente voltada para atender às regras ou determinações do mercado, isto é, para reproduzi-las e ampliá-las. Tal bibliografia ${ }^{10}$ acaba por modelar o estudante para que ele se comporte muito mais como um técnico profissional, que apenas reproduz as especificações das técnicas ensinadas por profissionais de marketing ou publicitários, tendo por finalidade que elas tenham serventia ou propiciem as vendas dos produtos desenhados dentro disso que se chama de fundamentos do design. Incidem mais sobre as técnicas de gestão, ou seja, aquilo que os agentes ${ }^{11}$ de produção de mercadorias determinam previamente para o incremento da produção de mais-valor, do que com a função utilitária do produto industrial. O uso do desenho como base do pensamento, materialização de operações que se realizam em alguma faculdade intelectual, praticamente se apaga. Não se discute sobre a obrigatoriedade que o designer deve considerar tendo em mente as circunstâncias mercantis que, de uma forma ou outra, influenciam na fase projetual.

Antes de avançar, porém, é importante ressaltar que essas orientações não são mais orientações técnicas em relação ao produto, em relação ao processo produtivo da sua fabricação, ou seja, que dizem respeito ao seu valor de uso ou seu sentido utilitário. Se é que ela um dia tenha existido realmente, verifica-se que a antiga noção, tão cara ao designer (atender a um briefing do dono da indústria, para que o produto industrial responda a uma demanda social), está sendo substituída por

por contínuas controvérsias com relação ao sentido do mundo e desse próprio mundo" (CATANI, 2017, p. 96).

${ }^{10}$ Ver por exemplo: PORTO, Bruno. Manual do freela: vende-se design. Autopromoção e portfólio para profissionais criativos. Rio de Janeiro: 2AB, 2011; LUPTON, Ellen. Novos fundamentos do design. São Paulo: Cosac Naify, 2008; BELTRÃO, André. Manual do freela: quanto custa meu design? - gestão financeira para designers. Rio de Janeiro: 2AB, 2010. Todos os exemplos citados faziam parte de programas de disciplinas da graduação cursada pelo autor do presente trabalho.

11 “A adoção do termo 'agente' por Bourdieu está relacionada ao seu esforço de construção de uma teoria da ação prática, ou seja, de um conhecimento sobre o modo como agentes concretos, inseridos em uma posição determinada do espaço social e portadores de um conjunto de disposições incorporadas, agem nas situações sociais. [...] as noções de agente e de habitus permitem a Bourdieu compreender o funcionamento macroestrutural da sociedade, particularmente os processos de dominação social, sem precisar supor que são intencionalmente constituídos, seja pelos indivíduos isolados, seja pelos grupos". (NOGUEIRA, 2017, p. 26-27) 
orientações que visam somente a produção de lucro. Por outro lado, percebe-se que esses profissionais se iludem em acreditar que possuem um dom, um talento inato, e que sua contribuição para a sociedade se limita apenas à manipulação dos aspectos da configuração estética e/ou funcional do produto ou mercadoria. Assim, tanto o profissional atuante no mercado de trabalho em que os designers atuam, quanto aqueles que decidem enveredar pelo Campo Universitário, como pesquisadores ou professores, tornam-se agentes de circulação com pouco ou nenhum senso crítico. É dizer, atuam profissionalmente sem questionar o estatuto ontológico dessa prática profissional e especialmente a quem o design serve.

$\mathrm{Na}$ base ou origem da questão referente à ideologia comercial encontra-se um fato histórico incontornável: a transformação daquilo que era comum e público, para uma dimensão privada, em que os interesses econômicos privados passam a ser compreendidos como sendo de interesse geral da sociedade. É preciso lembrar que desde o início da Idade Moderna, aquilo que era tido como bem comum - os campos selvagens e aquilo que neles era plantado, as florestas e os animais que nela viviam, as minas e seus minérios, os peixes dos mares, dos rios e lagos - era explorado coletivamente, tratando-se espaços públicos utilizados por todos aqueles que desejavam trabalhar. É claro que existiam regras para o exercício do trabalho e elas eram determinadas pelos poderosos de então, e muito do que era produzido acabava sendo expropriado das mãos dos que trabalhavam. Ocorre que essas coisas (bens) comuns começaram a ser privatizadas e as pessoas foram expulsas das terras e das atividades econômicas que realizavam, sendo que o final do processo foi marcado pela privatização do próprio trabalho, em que o trabalhador só poderia trabalhar se fosse como assalariado. Dessa maneira, pouco a pouco o campo foi sendo esvaziado e os trabalhadores conduzidos a trabalhar em usinas dentro das cidades. Essa nova compreensão em relação às coisas comuns e ao trabalho privatizado, totalmente mergulhada na ideologia comercial do capitalismo, pode explicar e justificar a formação de uma consciência individual como se ela atendesse à vontade geral.

Uma vez compreendendo essa transformação e naturalização dos interesses econômicos comuns em privados, é possível entender por qual motivo o Estado acabou por se imiscuir na formação profissional dos designers (SELLE, 1972, p. 28-29, tradução nossa). Afinal, desde o movimento Arts and Crafts (Grã-Bretanha) 
e do Deutscher Werkbund (Alemanha), quando a educação de modo geral começou a ser pública e obrigação do Estado, celebra-se a noção de que os profissionais do Campo do Design são meros executores da vontade social.

Selle (1972) questionou a atrofia da consciência de se correlacionar com o crescimento do design na esfera pública e os interesses particulares ou privados dos produtores para produzirem um efeito cumulativo, sancionando a teoria social do design com falsidades palpáveis. Evidentemente que essa afirmação contra a verdade dos fatos também foi naturalizada e hoje está consolidada a noção de que os designers trabalham para atender às necessidades da sociedade. Em parte, isso é verdade, mas o produto do seu trabalho, o desenho dos objetos industriais, atende mais à produção de mais-valor do que aquilo que os usuários precisam. Logo, fica assim caracterizado que as escolas de design, as mais importantes instâncias de legitimação disso que é o design, a sua dimensão ontológica, trabalham mais tempo para justificar que as mercadorias produzidas são socialmente necessárias, do que o que elas realmente o são. Percebe-se, pois, a recorrência de designers como se fossem apenas reprodutores de ideias e ideais mercantis, que têm por finalidade unicamente a produção de objetos que gerem lucro. O sentido primeiro, que o objeto industrial tivesse valor de uso social, foi transformado em um valor simbólico. O valor de um objeto concreto que serve para isso ou aquilo foi transformado em um valor monetário ou financeiro.

O que se percebe nesses orbitais acadêmicos é a existência de uma forte Violência Simbólica ${ }^{12}$, uma verdadeira lavagem cerebral em um importante momento de formação profissional ou formas "brandas" de violência de dominação que conseguem ganhar a adesão dos dominados (MAUGER, 2017, p. 360). Tal violência simbólica age através de um meio inconsciente, do habitus ${ }^{13}$ que inculca coercitivamente uma cultura e crenças em muitos valores, mas que são tidos como saberes necessários para a educação dos designers desde os primórdios de sua formação.

\footnotetext{
${ }^{12}$ Termo cunhado por Pierre Bourdieu. Ver, CATANI, Afrânio Mendes et alii. (Orgs.) Vocabulário Bourdieu. Belo Horizonte: Autêntica Editora, 2017, p. 359.

${ }^{13} \mathrm{O}$ termo habitus aqui é um termo técnico, tal como Pierre Bourdieu o definiu. Para uma definição de habitus, ver: "A gênese dos conceitos de habitus e de campo". In.: BOURDIEU, Pierre. O poder simbólico. Rio de Janeiro: Bertrand Brasil, 2003. Ver também: "O mercado de bens simbólicos". In.: BOURDIEU, Pierre. A economia das trocas simbólicas. São Paulo: Perspectiva, 2001.
} 
É notável que desde os anos 1990 (MATIAS, 2014, p. 28) a atividade profissional do designer esteja assumindo cada vez mais um perfil tecnicista e mercantil, contrária ao atendimento das demandas sociais coletivas e afastando-se das formulações contestatórias que marcaram seu surgimento, em escolas como as Vkhutemas (na União das Repúblicas Socialistas Soviéticas), e na Bauhaus (na República de Weimar e, posteriormente, em Dessau, ambas na Alemanha). Importante perceber que tais escolas (principalmente a Bauhaus, pois as Vkhutemas são raramente citadas nos livros de formação) são principalmente mencionadas pelas suas contribuições técnico-formais, e não pela grande contribuição social e formação de profissionais que questionaram de fato o status quo do Campo do Design.

Mesmo que não tenham sido aplicadas pela grande indústria e que muitas delas tenham ficado como sendo exercícios didáticos para formação de desenhistas industriais, é importante ressaltar que essas modificações ou contribuições técnicoformais trazidas pelas escolas de design não foram ou não eram um mal em si mesmas. Muitas vezes elas concorreram para a melhoria do valor de uso dos produtos e algumas delas foram bastante necessárias ou úteis, sendo empregadas dentro de uma função nitidamente social. Mas depois da Segunda Guerra ou mesmo durante o período da guerra essas modificações passaram a ser ensinadas para serem produzidas descoladas ou alienadas das demandas sociais concretas, tal como foi o caso da Bauhaus quando levada para Chicago. Esses ensinamentos técnico-formais, que hoje se chamam de metodologia projetual, fórmula ou teoria destacada para realização do projeto de um objeto industrial, quais sejam protocolos carentes de algo quando se tratava de soluções de problemas técnicos, quando as pessoas não entendiam muito bem para que as inovações técnicas haviam sido introduzidas. As pessoas não entendiam principalmente a modificação da forma de um objeto industrial. Não entendiam por que mudar uma configuração (Gestaltung) quando se tratavam de alterações formais, isto é, de estilo artístico. $\mathrm{O}$ estilo moderno era apresentado como se fosse uma demanda técnica ou utilitária, isto é, form follows function (a forma segue a função). É necessário lembrar que isso que se chama de modernismo (seja o termo modernismo uma referência a uma inovação técnica, seja ele o uso de uma "nova" forma artística) antes de ser um 
estilo, foi uma causa ideológica. ${ }^{14}$ Hoje, essa denominada forma revolucionária do objeto industrial é apenas uma resposta estética a um protocolo de etapas a serem seguidas, esvaziada politicamente, e que o campo denominou de "metodologia projetual".

A famosa frase de que a "forma segue a função", um dos importantes lemas da Bauhaus, ainda hoje um dos "mantras" nos cursos de graduação de design, não foi apenas uma maneira de ensinar que o excesso de ornamentos era dispensável no projeto de design, mas também porque eram socialmente inúteis. O termo "a forma segue a função" não se tratava de uma afirmação de que o ensino deveria ser fundamentalmente voltado para o projeto de coisas utilitárias ou funcionais, ou apenas para atender às demandas concretas da sociedade. Ensinar a desenhar xícaras de modo que uma se encaixasse na outra, para economizar espaço de armazenamento, tinha um sentido político ou ideológico para a defesa do bem comum. Em uma época de grande escassez de materiais e mão de obra para construção, onde os espaços de armazenamento eram exíguos, quando a Europa estava destruída depois da Primeira Guerra Mundial ${ }^{15}$, e havia uma grande demanda por residências, houve uma opção política pela construção de residências para os trabalhadores. Ainda que as moradias fossem menores e fabricadas industrialmente em série, tratava-se de um projeto social para atender trabalhadores assalariados, uma ação política de governos sociais-democratas. Essas residências, incluindo os móveis e objetos que elas abrigavam, eram formalmente "novas" ou "modernas", ou seja, possuíam um desenho estranho ou alheio às configurações tradicionais. Se a construção dos espaços residenciais era muito cara e por essa razão as cozinhas eram pequenas, se justificava ensinar que era melhor ou mais indicado o projeto de xícaras que se encaixavam umas nas outras. Ademais, na URSS ou na Alemanha da República de Weimar, embora fossem regimes com propósitos diferenciados (o primeiro mais radical e o segundo exercendo pouca ou nenhuma pressão à burguesia), estava claro que a indústria deveria continuar a produzir cada vez mais, pois era necessário produzir o mais-valor. Para um ou outro

${ }^{14}$ KOOP, Anatole. Quand le moderne n'était pas um style, mais une cause. Paris: École Nationale Supérieure des Beaux-Arts, 1988.

${ }^{15}$ No caso da Vkhutemas, na União das Repúblicas Socialistas Soviéticas, o problema foi bem maior, pois tinha havido além da guerra contra os alemães, uma guerra civil. Havia uma economia destruída e a vontade política de retomada industrial, mas agora não seria para uns poucos consumidores privilegiados, mas sim para a maior parte da população. Desenhar uma garrafa térmica para mil pessoas não era o mesmo que projetá-la para dez ou vinte milhões. 
regime, a riqueza produzida pela indústria propiciava riqueza e estabilidade social. Fora dessa situação concreta, xícaras que se encaixavam ou com configurações excêntricas pareciam não ter sentido. Mas nos dias de hoje existe um paralisante esquecimento em formular outras questões que circunscrevem a produção de objetos industriais. Normalmente eles estão voltados apenas para os aspectos de natureza estética, em que a dimensão funcional parece se eclipsar. No âmbito do ensino de jovens designers, entende-se que seria preciso perguntar outras coisas, tal como funcionar para quê ou para quem? Ou, ainda, e o que parece ser mais pertinente, indagar se o funcionalismo não se transformou em estilo, isto é, se perdeu seu valor de uso e passou a ser valor de troca simbólica.

Assim, o pretendido aqui foi, com base em autores que trataram sobre ideologia no Campo do Design, questionar a forma como se estuda e se aplica os ditos fundamentos do design numa sociedade onde certamente existem interesses de cunho político-mercantil. E que os pares do campo não levam em consideração o modo de produção vigente, o capitalismo, que tem por finalidade única a produção de lucro, esquecendo-se daquilo que outrora se chamava de bem comum. Logo, para a permanência desse modus operandi torna-se imprescindível que haja a inexistência de qualquer tipo de pensamento que o questione, ou seja, o pensamento crítico. Para realizar essa análise crítica será feita, também, uma breve explicação de conceitos técnicos, assim como suas referências bibliográficas, isto é, as teorias sociológicas, tais quais as noções de Campo, Habitus e Violência Simbólica. Importa ainda constar que foram empregadas principalmente as teorias sociais de Pierre Bourdieu. Do mesmo modo, julgou-se imprescindível utilizar a noção de fetichismo da mercadoria, de Marx e Engels. Essa pequena explanação introdutória quanto à metodologia, se deveu ao fato de a teoria social de Bourdieu, de modo geral, ser entendida como em desacordo com as teorias de Marx e Engels. Contudo, verifica-se também que já existem estudos que pretendem reverter essa tendência antagonista, a exemplo do trabalho de Michael Burawoy. ${ }^{16}$

\section{2. A Violência Simbólica no estudo de design}

No presente subcapítulo será feita uma análise crítica sobre o emprego de

${ }^{16}$ BURAWOY, Michael. O marxismo encontra Bourdieu. Campinas, São Paulo: Editora da Unicamp, 2010. 
ideologias empresariais nas instâncias de ensino do Campo do Design. Nesse percurso indaga-se sobre quais seriam os motivos que levam os agentes de legitimação do campo a empregar fundamentos teóricos cada vez mais voltados para um conjunto sistemático de opiniões e ideias acabadas sobre o mercado, em que se encontra uma miríade de termos tais como gestão, empreendedorismo, competitividade, inovação, informação (MATIAS, 2014, p. 18). Além disso, percebe-se cada vez mais a implantação de disciplinas que operam no mesmo sentido citado acima, como Gestão do Design, Marketing, Agenciamento profissional e Design aplicado à publicidade. ${ }^{17}$

Cria-se, desta forma, um solo fértil para o desenvolvimento de ideologias empreendedoristas e gestoriais dentro dos próprios trabalhos acadêmicos dos estudantes. Tudo isto tendo como substrato a promessa de empregabilidade, própria de uma educação toyotizada. (Idem., ibidem, p. 24)

Mas será que o motivo seria apenas a promessa de empregabilidade? Julga-se que não. A utilização desse tipo de ensino parece estar associada a uma recorrente falta de produção crítica, e existem interesses para que isso assim permaneça. E certamente não são interesses individuais. É o próprio Campo do Design que constitui o habitus coletivo e inconsciente no qual os designers operam, em uma disposição que determina o que eles escolhem e que os fazem pensar que são donos de tais disposições (CIPINIUK, 2017, p. 105).

Porém os designers, por causa do habitus coletivo já citado, parecem não perceber que em todos os campos ${ }^{18}$ existem dominados e dominantes. "Enquanto as estratégias de dominação vêm reforçar a ciência oficial em seu funcionamento e em sua estrutura epistêmica, as estratégias de subversão têm em mira a fundação de uma ordem científica herética” (RAGOUNET, 2017, p. 69). No espaço de concorrência que é o Campo Científico ${ }^{19}$, quem determina e legitima o que deve ser estudado são os dominantes de tal campo, de modo que quem se atreve a discordar e criticar o pensamento hegemônico acaba por se tornar "herege", pois vai contra

\footnotetext{
17 Todas as disciplinas citadas foram cursadas pelo autor que escreve o presente capítulo em sua graduação em Design Gráfico na Universidade Federal de Pelotas.

${ }^{18} \mathrm{O}$ termo campo aqui é um termo técnico, tal como Pierre Bourdieu o definiu. Para uma definição de campo, ver: "A gênese dos conceitos de habitus e de campo". In.: BOURDIEU, Pierre. O poder simbólico. Rio de Janeiro: Bertrand Brasil, 2003. Ver também: "O mercado de bens simbólicos". In.: BOURDIEU, Pierre. A economia das trocas simbólicas. São Paulo: Perspectiva, 2001.

${ }^{19}$ Termo cunhado por Pierre Bourdieu. Ver, CATANI, Afrânio Mendes et alii. (Orgs.) Vocabulário Bourdieu. Belo Horizonte: Autêntica Editora, 2017, p. 68.
} 
tal pensamento. Esses são os dominados do campo e acabam por ser "privados da possibilidade de uma liberdade baseada na tomada de consciência” (MAUGER, 2017, p. 360). Tal relação de poder se denomina Violência Simbólica, e são essas relações que ocorrem também no Campo do Design. Violência Simbólica é

[...] a coerção que se institui unicamente por intermédio da adesão que o dominado não pode deixar de dar ao dominante (portanto, à dominação) quando, para pensá-lo - ou, melhor ainda, para pensar sua relação com ele -, o dominado dispõe apenas de instrumentos de conhecimento que tem em comum com o dominante, os quais, limitando-se a ser forma incorporada da estrutura, da relação de dominação, fazem com que essa relação pareça natural [...] (Idem., ibidem.).

Os dominantes do Campo do Design parecem insistir na permanência das já citadas bibliografias que defendem o ensino do design apenas como um meio para a produção do mais-valor, mas muitas vezes camufladas de termos como "funcional" ou human-centered. E é curioso perceber que a maioria se cala e aceita as noções da ideologia mercantil como fatos incontestáveis. “A violência do Estado é exercida sobre nós através da inculcação de categorias por meio do sistema educacional, que produz 'mentes dóceis' e, não é supérfluo recordar, docilis deriva de docele, ensinar" (CATANI, 2017, p. 98). O que se percebe é que existe uma ideia dentro das instâncias de legitimação, especialmente aquela parcela que se dedica ao ensino do design, que procura se afastar da questão política que existe na sociedade capitalista, mantendo as "mentes dóceis", mas, na verdade, "nenhuma posição de neutralidade é esvaziada de sua condição ideológica ou despolitizada" (CIPINIUK, 2017, p. 104). É dizer, mesmo as noções que se julgam estar afastadas da questão política são noções ideológicas.

Para Cipiniuk (2017) não há ingenuidade entre os pesquisadores do Campo do Design ao adotarem uma ou outra postura teórica. A ação política não é medida pela intenção, mas sim pelos resultados e efeitos que tais ações geram, trata-se, portanto, além de ignorância, intencionalidade. A falta de crítica é também uma escolha ideológica, pois reproduz a ideia de que o projeto de design tem apenas "processos de produção de planificação e sua estrutura técnico-racional” (SELLE, 1972, p. 35). 
Ocorre que os poucos pesquisadores que eventualmente examinam para o que serviria essa racionalização ou harmonia formal se perguntam o porquê dessa investigação de caráter formalista. Para os pares, parece que a identificação dessa homologia é o suficiente para que uma pesquisa científica seja realizada corretamente. Poucos ou praticamente nenhum pesquisador ainda se debruçou sobre o que me parece ser fundamental: indicar que entre as etapas de desenvolvimento de um projeto de design nenhum designer se preocupa com o fato de que, ao incluir em suas variáveis, critérios para evitar custos desnecessários e, assim, produzir objetos mais baratos, trata-se na verdade de produzir mais-valia para os donos de indústria. (CIPINIUK, 2017, p. 100)

Parece claro que, enquanto se reproduzir tal tipo de noção, o Campo do Design estará fadado a apenas projetar o que os produtores impõem, sem questionar, como dito anteriormente, para quem ou para quê se está projetando. Muitas vezes o designer acredita que sua função social é meramente técnica ou, então, o emprego de uma nova forma, e isso se deve muito à ausência de bases epistemológicas mais aprofundadas, ministradas ainda na graduação.

Não há dúvida de que enquanto se continuar a pensar design sem raciocínio crítico dentro das instituições de ensino de design, se estará contribuindo para o (des) preparo de profissionais que atendem à produção industrial sem o mínimo questionamento social. Desta forma, se colabora apenas para a manutenção de uma sociedade que trabalha de forma alienada, sem entender que, enquanto dominados do campo apenas contribuem para a manutenção do status quo classista e burguês.

\section{3. O fetichismo da mercadoria no trabalho do designer}

Já se analisou a questão da ideologia empresarial no meio acadêmico do ensino de design, no subtítulo acima. O pretendido no presente subcapítulo é ordenar gradualmente os elementos constitutivos (de novo, de forma crítica) da presença de tais ideologias no mercado de trabalho em que o designer atua.

O designer, por projetar as mercadorias, tem o poder de "moldar os mitos numa forma sólida, tangível e duradoura, de tal modo que parecem ser a própria realidade" (FORTY, 2007, p. 15). É dizer, o designer contribui para a "camuflagem" da mercadoria com a finalidade de obter sucesso comercial (lucro). A mercadoria deve incorporar e materializar as ideias que servem para serem 
comercializáveis, e o trabalho do designer é "provocar a conjunção dessas ideias e os meios disponíveis de produção" (FORTY, 2007, p. 16). O que resulta na manufatura encarnar os mitos sobre o mundo, "mitos que acabam parecendo tão reais quanto os produtos em que estão encarnados" (Idem., ibidem.).

O designer é também o responsável por criar um estranhamento do trabalhador para com a manufatura que ele cria, pois, ao projetar produtos carregados de mitos, o trabalhador acaba não se reconhecendo na mercadoria criada. Marx (1994) chamou isso de "o misterioso da forma mercadoria" ou "fetichismo da mercadoria".

Karl Marx tinha uma expressão adequada a essa psicologia do consumo, chamava de "fetichismo de mercadorias". Em O Capital ele escrevera que todo objeto manufaturado, colocado sob o capitalismo moderno, torna-se um "hieróglifo social"; através dessa expressão ele queria dizer que as inequidades nas relações entre o patrão e o operário na produção desse objeto poderiam ser dissimuladas. A atenção era desviada das condições sociais sob as quais os objetos eram feitos para os objetos em si mesmos, caso as mercadorias adquirissem um sentido, um mistério, um conjunto de associações que não tivessem nada a ver com seu uso. (SENNETT, 2016, p. 214)

O que o projetista "cria" são os tais "hieróglifos sociais". Não se trata de mercadorias criativas e utilitárias, mas mercadorias "diferenciadas", isto é, que possuem apenas diferenciação em relação às outras como forma de gerar mais-valor para o empresário ou dono de fábrica. Ainda que sejam calças de cor amarelas, mas que poderiam ser verde limão. Se são rasgadas, ou ainda estreitas nas pernas, mas poderiam ser largas, ao fim e ao cabo continuarão sendo calças. E isso é típico do nosso modelo econômico, o capitalismo. O trabalho estranhado ou alienado do designer consiste em disfarçar ou mudar a forma, sem que ele saiba o que está fazendo. Mas existe a crença, ensinada largamente nas instâncias de ensino do Campo do Design, de que "a forma segue a função". Se esse argumento possuísse alguma ontologia, todos os objetos com a mesma finalidade deveriam apresentar a mesma forma (FORTY, 2007, p. 21), o que certamente não ocorre.

Ao "disfarçar" ou camuflar as mercadorias, o designer apenas contribui para que se perverta o valor de uso da mercadoria em valor de troca simbólica. Dessa maneira, criam-se objetos frívolos, com a função de gerar apenas prestígio ou distinção social para quem possui meios para adquiri-lo. E essas noções estão 
carregadas de ideologia empresarial, mercantil. Atualmente, os componentes estéticos dos objetos frequentemente desempenham um papel mais relevante na competição de mercado ou na esfera do consumo do que seu princípio construtivo e seu valor utilitário (SELLE, 1972, p. 15).

Ademais, o designer alienado acredita que cria objetos com total autonomia, sem perceber que está apenas colaborando como agente de reprodução de valores sociais da burguesia, pois quem decide qual o design que será utilizado é o empresário. Tal crença é o que Cipiniuk (2014) chama de carismática.

\begin{abstract}
Podemos afirmar com alguma certeza que a maior parte da literatura sobre o campo do design normalmente é dedicada à defesa da noção de que o objeto de design possui um 'je ne sais quoi $\cdot{ }^{20}$ Essa literatura advoga em benefício da reprodução da crença de que o objeto de design é carismático, isto é, possuidor de uma autoridade, uma fascinação irresistível que se exerce sobre aqueles que o observam, supostamente proveniente de poderes sobrenaturais. (CIPINIUK, 2014, p. 31)
\end{abstract}

Essa crença está diretamente ligada ao fetichismo da mercadoria, pois permite que o designer se coloque como um criador que realmente pode e deve elevar a mercadoria ao nível do feitiço ou encantamento do consumidor. Acontece que a realidade não é tão otimista e essas crenças pertencem à dimensão idealista, isto é, possuem bases míticas, com pouco trânsito entre as outras disciplinas da área social (Idem., ibidem.). Percebe-se aqui novamente o silêncio da categoria profissional do designer pela falta de conhecimento ontológico e epistemológico das práticas dos profissionais do campo, uma vez que não se questiona o que se está projetando. Há que se indagar por qual motivo essa cultura de auto ilusão se implantou e persevera em sua reprodução.

O que se pode observar é uma "crença" na legitimação de uma forma de trabalho tecnicista, sem o menor raciocínio crítico entre os pares do campo, teóricos e práticos da profissão. O design é uma forma de trabalho como qualquer outra. É uma prática social coletiva e precisa se afastar de crenças idealistas que têm origem em ideologias que defendem a manutenção da divisão entre classes sociais.

Chegou-se a um ponto que o que se almeja na profissão é ser criador de objetos de desejo, de tal forma que o designer "bem-sucedido" é aquele que projeta objetos

\footnotetext{
${ }^{20}$ Do francês "um não sei o quê", uma qualidade intangível, inexprimível com palavras, mas percebida concretamente através dos sentidos.
} 
de luxo. "O design não é mais pensável fora da estrutura do empreendimento cultural; as exposições, as amostras e os prêmios garantem o reconhecimento público de seu valor" (SELLE, 1972, p. 41, tradução nossa). E quem consome design está associado diretamente a tal crença à produção da categoria, isto é, acreditam que um objeto que possui design - termo este que é equivocado, pois design não é adjetivo, e sim substantivo - é aquele que se diferencia por um "toque" criativo. Essas crenças são, novamente, de cunho idealista.

A realidade fala uma língua diferente. Concebido com uma linguagem internacional comum, o design tornou-se, acima de tudo, um chavão que sugere associações com o chique, a bela forma, certos personagens de uma existência estetizada e um conforto civilizado, representações, enfim, de "um futuro de baunilha refrescante, perfumada, doce e apetitosa", como já foi dito sarcasticamente. (SELLE, 1972, p. 28, tradução nossa)

Os responsáveis por essas crenças carismáticas são os agentes de legitimação do campo, isto é, os pares que atuam na profissão, que reproduzem a cultura de que o design possui essa noção carismática e de que os designers são criadores possuidores de um dom. Parece ser que a porta de entrada para uma análise crítica sobre o campo deve ser a tomada de posição política para acabar com tais crenças, pois estas apenas contribuem para a continuidade desse quid pro quo ${ }^{21}$, no qual os produtos de trabalho se tornam mercadorias, "coisas sensíveis, suprassensíveis, metafísicas e sociais” (MARX, 1994, p. 81). E é justamente nessa transformação que ocorre o estranhamento ou a alienação do trabalhador para com o seu trabalho.

\section{Conclusão do Capítulo 3}

Pensar a prática do design de maneira crítica parece ser imprescindível para a criação de agentes que questionem o modo de produção em que estão inseridos. Percebe-se que, tanto no Campo Universitário quanto no mercado de trabalho do Campo do Design, o pensamento crítico se encontra cada vez mais escasso. Tal fato certamente se deve aos interesses classistas e burgueses em manter os dominantes como agentes de manutenção dos valores, isto é, agentes conservadores.

\footnotetext{
${ }^{21}$ Quid pro quo é uma expressão latina que significa "tomar uma coisa por outra". Faz referência, no uso do português e de todas as línguas latinas, a uma confusão ou engano.
} 
Embora os agentes de produção e de recepção também colaborem, a conservação do campo se deve principalmente aos agentes de legitimação, que, por estarem inculcados coercitivamente pelo habitus, perpetuam crenças ultrapassadas de maneira inconsciente. Com isso se legitima o pensamento acrítico no campo, o qual forma cada vez mais profissionais técnicos, que julgam que fazer design é seguir uma metodologia projetual vagamente funcionalista ou unicamente com o apoio de aplicação de estilos, em um campo sem espaço para questionamentos sociais. Tais profissionais se iludem e iludem aos agentes de produção, ao achar que quem desenha ou elabora os projetos são possuidores de um talento inato, o dom da criatividade, e talvez isso seja o fator de maior relevância pelo silêncio e distanciamento de qualquer raciocínio direcionado a questionar os valores atuais.

Se faz design para os produtores, isto é, empresários ou donos de fábricas. E isso ocorre também quando o profissional é empreendedor (termo este corriqueiro no campo), pois o cliente é externo ao empreendedor. É dizer, são empresários extrínsecos ao campo que formulam briefings para que os designers reproduzam e se mantenham como dominados, pois possuem muito pouco (ou nenhum) poder na tomada de decisão sobre as mercadorias que estão projetando.

Os profissionais do campo, sejam eles os pertencentes do meio acadêmico ou os que integram o mercado de trabalho, não percebem que ao se manterem acríticos estão ajudando a manter, também, as ideologias empresariais e mercantis que perpetuam a desigualdade de classes entre trabalhadores e seus patrões. Essas ideologias, como se analisou ao longo do texto, são largamente ensinadas no curso da graduação e contribuem para a manutenção de trabalhadores alienados, que não percebem para quem ou para quê estão projetando as mercadorias.

Por fim, conclui-se que para o pensamento crítico se tornar eficaz a longo prazo, deve-se primeiramente romper com o emprego de teorias levianas e carismáticas e começar a perceber a função social do designer, trazendo à consciência os reais fundamentos do design. Para tanto, torna-se necessário tomar os fundamentos aparentes (empresariais, mercantis), negá-los e superá-los, de forma a ir além dessas formulações superficiais. Dessa maneira se poderá cambiar a visão de que o profissional de design é apenas um técnico dotado de poderes criativos e começar a percebê-lo como um trabalhador, que, como tal, possui responsabilidades reais com demandas sociais concretas. 


\section{TODA ESCOLHA ESTÉTICA É UMA ESCOLHA POLÍTICA}

Calcada nas postulações de estudiosos de arte e design, o que se propõe no presente capítulo é uma breve abordagem, com a finalidade de compreender as razões de os objetos de arte, tal como os objetos industriais, avizinharem-se parecidos, isto é, pode-se identificar uma homologia entre uma e outra forma de configuração desses dois objetos, mas não apenas isso. Mais precisamente, a intenção é a de evidenciar o uso dos mesmos termos ou conceitos para o estudo dos objetos de arte e os objetos industriais. Não é o pretendido fazer um estudo detalhado do que é a ciência filosófica do belo ou da estética ou da filosofia da arte, nem uma análise histórica profunda sobre os estetas do passado, mas sim construir uma análise crítica sobre o surgimento da disciplina Estética, inexistente até a segunda metade do século XVIII. Defende-se que a estética é uma consequência ou um arbitrário cultural da sociedade burguesa, uma disciplina teórica que postulava princípios fixos para a relação entre a arte e o gosto daquela época, mas depois transformou-se em uma ciência chave para o estudo da forma na arte e nos produtos industriais. A hipótese sugerida é: tal como o gosto, toda escolha estética é política, e os processos por onde se enunciam os juízos, as preferências ou predileções, outrora pertencentes exclusivamente ao âmbito da filosofia, se dão basicamente através dos mesmos princípios que os pares do Campo do Design empregam contemporaneamente para a manutenção de ideais de consagração e legitimação do seu campo profissional. Os produtores de objetos industriais são conservadores, defendem a crença de que projetam e/ou constroem os objetos com total autonomia, autoridade e individualismo, isto é, no pleno exercício de sua subjetividade, escolhendo (ou até mesmo "criando") novos estilos ou tal como dizem, estéticas. E quando estes princípios são seguidos à risca ou respeitados, os pares do campo afirmam que todas as pessoas "gostam" daquilo que veem. Tais agentes parecem esquecer de que projetam e constroem valores de legitimação não por conta de princípios eternos ou fixos, mas dentro de uma realidade social dinâmica, portanto são políticos: o modo de produção industrial capitalista, em que as tomadas de 
decisão são efetuadas por agentes dominantes, possuidores de capital financeiro e simbólico, e que a manutenção de certos aspectos estéticos consagrados ajuda a manter o status quo de agentes dominadores e agentes dominados no campo.

\section{1. Uma brevíssima história da Estética}

No Campo do Design o substantivo "estética" designa uma parte da ciência filosófica que nos dias de hoje trata confusamente do design, da arte e do belo. Muitos designers falam da "estética" de um objeto industrial, mas querem dizer algo sobre a sua configuração (gestaltung) ou estilo, pois não são rigorosos no emprego de certos termos ou conceitos filosóficos. A Estética como ciência, embora seja um apêndice da filosofia dedicada ao estudo do belo, também se distingue da Filosofia da Arte, que trata particularmente da definição disso que é a Arte, pois existem coisas belas que não pertencem ao mundo da arte. A Estética como ciência do belo foi introduzida por volta da metade do século XVIII por Baumgarten, num livro denominado Aesthetica, no qual ele defendia a tese de que os objetos da arte são objetos confusos, porém claros (sensíveis, mas “perfeitos”). Importante ressaltar que o termo "confusão" não significa, aqui, "mistura", mas "fusão", pois em sua interpenetração, os elementos da representação estética, que são sensíveis, mantêm "unidades discretas características do pensamento conceitual" (EAGLETON, 1993, p. 19). Portanto o substantivo significa "doutrina do conhecimento sensível", isto é, o que se pode saber empregando os sentidos, haja vista que até esse momento os pensadores julgavam que só era possível saber empregando a razão. Antes da noção de estética, inexistente até então, a arte e o belo eram conceitos diferentes e independentes, e esta doutrina, a da arte, os antigos chamavam com o nome do seu próprio objeto, poetica, a qual se considerava simplesmente a produção de imagens. A arte, tal como a entendemos hoje, uma espécie de janela para o mundo superior das ideias, só passou a ser considerada depois do Neoplatonismo do Renascimento. Depois disso, a arte foi adquirindo autonomia e passando a ser uma ciência que operava com princípios irracionais, ou fora da dimensão abrangida pela razão. O belo, por sua vez, não se incluía na poética e era considerado à parte. Para Platão, o belo também era diferente da arte. Era a manifestação evidente dos valores morais, das Ideias, e a arte era uma imitação das coisas sensíveis, em um terceiro nível do real, lembrando que o real, para o referido 
filósofo, era o que existia no mundo das ideias e não o que se podia ver pelo sentido da visão no mundo sublunar. Já para Aristóteles o belo representava a ordem, a simetria e também adotava a arte como imitação das coisas do mundo sublunar (ABBAGNANO, 1998, p. 367).

Porém, a partir do século XVIII, a arte e o belo passaram a ser vistos como algo associado ou complementar, "como objetos de uma única investigação" (Idem., Ibidem.). E é a partir desse momento histórico que se pretende fazer a investigação acerca do uso de tais termos ou conceitos para o estudo dos objetos de arte e dos objetos industriais. Pois, não por acaso, o novo conceito de estética, ou a ciência da estética, se constrói na passagem do Ancien Régime para a modernidade. Modernidade aqui não significa o movimento artístico do Modernismo, que se deu no final do século XIX e início do século XX com suas diferentes experimentações e vanguardas artísticas, mas para o resultado da longa construção histórica da Idade Moderna, que se fez desde o início do Mercantilismo do cinquecento, depois por Kant, com a crise da metafísica católica e, por fim, culminando no Iluminismo.

Muitos foram os filósofos que se debruçaram na questão da estética, tais quais Hume, Kant, Scheling, Hegel, Lukács, Rancière entre tantos outros além do supracitado Baumgarten. Contudo, não se deseja investigar o assunto empregando apenas a filosofia da estética, mas também aquilo que os historiadores da arte chamam de "literatura artística". ${ }^{22}$ Textos de filósofos, artistas e outros teóricos das ciências humanas e sociais também serão examinados para definir se é possível empregar os mesmos termos ou conceitos para os objetos industriais e para os objetos artísticos. E a hipótese central do presente capítulo é que a escolha estética no Campo da Arte e no Campo do Design é uma escolha política.

Qualquer um que examine a História da Filosofia europeia desde o Iluminismo será tocado pela curiosa prioridade atribuída às questões estéticas. Para Kant, a estética guarda uma promessa de conciliação entre a Natureza e a humanidade. Hegel dá à arte um estatuto menor no corpo de seu sistema teórico, embora the dedique um tratado de exagerado tamanho. A estética, para Kierkegaard, deve recuar diante das verdades mais elevadas da ética e da fé religiosa, mas não deixa de ser uma preocupação recorrente em sua obra. Para Schopenhauer e Nietzsche, de forma contrastante, a experiência estética representa a forma suprema

\footnotetext{
${ }^{22}$ SCHLOSSER, Julius Von. La Littérature artistique: Manuel des sources de l'histoire de l'art moderne. Trad. Jacques Chavy. Paris: Flammarion, 1984.
} 
do valor. As alusões impressionantemente eruditas de Marx à literatura mundial combinam-se com a confissão modesta de Freud, de que os poetas disseram tudo antes dele. Em nosso século, as meditações esotéricas de Heidegger culminam numa espécie de ontologia estetizada, enquanto o legado do marxismo ocidental, de Lukács a Adorno, dedica à arte um privilégio teórico surpreendente, à primeira vista, em uma corrente de pensamento materialista. Nos debates contemporâneos sobre a modernidade, o modernismo e o pós-modernismo, a "cultura" parece ser a categoria-chave para a análise e a compreensão da sociedade capitalista tardia. (EAGLETON, 1993, p. 7)

Eagleton (1993), em seu livro A Ideologia da Estética afirma que com o nascimento da estética, a esfera da arte começa a sofrer certa abstração e formalização da teoria moderna (Idem., p. 8). Para ele, a estética é sempre uma espécie de projeto contraditório e autodestrutível, pois ao promover o valor teórico de seu objeto, arrisca-se a esvaziá-lo da sua especificidade material. Defere que a linguagem que eleva a arte a ser o mais alto empreendimento do espírito humano, arrisca-se perpetuamente a destruí-la. $\mathrm{O}$ argumento central do autor é de que a importância da estética como ciência se faz porque ao tratar de arte, a estética também se refere a questões que se encontram no centro da luta de classes (Idem., Ibidem.). $\mathrm{O}$ autor também adjudica que a estética desafia poderosos e formas ideológicas dominantes, com a emergência da burguesia primícia, em que certos conceitos estéticos exercem "um papel central e intensivo na constituição da ideologia dominante" (Idem., p. 9).

Como dito anteriormente, o surgimento da ciência filosófica da Estética se deu na segunda metade do século XVIII (Baumgarten escreve seu Aesthetica em 1750), e tal não por acaso. Com efeito, em decorrência da queda dos regimes absolutistas, o homem burguês quebra com o particularismo e o privilégio do Ancien Régime, instalando a classe média e, por consequência, um novo "tipo" de sujeito. Um sujeito individualizado, liberal, que já não obedece às regras das cortes absolutistas, mas às do mercado burguês. "O individualismo possessivo abandona cada sujeito em seu próprio espaço privado, dissolve todos os vínculos positivos entre os sujeitos e os mergulha no antagonismo mútuo" (EAGLETON, 1993, p. 24).

A arte como uma noção que designa uma forma de experiência específica só existe no Ocidente desde o final do século dezoito. Todos os tipos de artes e práticas existiam antes, certamente, entre as quais um pequeno número se beneficiava de status privilegiado, devido não à sua excelência intrínseca, mas ao seu 
lugar na divisão das condições sociais. (RANCIÈRE, 2013, p. IX, tradução nossa)

A "divisão das condições sociais", que significa a impossibilidade ou improbabilidade de ascensão social, muda conforme a burguesia avança, abrindo espaço para o surgimento de uma classe média cada vez mais letrada e, por consequência, cada vez mais individualizada. É importante lembrar que justamente nesse momento histórico surge o racionalismo francês (cerca de cem anos antes era publicado o Discurso sobre o Método, de Descartes). Dessa maneira, racionalizouse também "toda a região da percepção e sensações humanas" (EAGLETON, 1993, p. 17). A primeira distinção que o termo "estética" faz inicialmente não é aquela entre arte e vida, mas entre o material e o imaterial (Idem., ibidem.).

\section{O regime estético das artes sob a ótica sociológica}

Jacques Rancière (2013) propõe um "regime estético da arte", no qual ele constrói uma miscelânea de análises de percepções, sensações e interpretações de arte, que são constituídos e transformados por dar as boas-vindas a imagens, objetos e performances que podem parecer uma oposição à ideia de belas artes (RANCIÈRE, 2013, p. X). Assim, Rancière analisa imagens e objetos de design como pertencentes a esse regime estético.

Há certamente razões para essa escolha, mesmo que, como todas as boas razões, sejam descobertas tardiamente. Histórias e filosofias influentes da modernidade artística identificam-na com a conquista da autonomia de cada arte, expressa em obras exemplares que rompem com o curso da história, separando-se da arte do passado e das formas "estéticas" da vida prosaica. Quinze anos de trabalho me levaram às conclusões exatamente opostas: o movimento pertencente ao regime estético, que sustentava o sonho da novidade artística e a fusão entre arte e vida subsumida sob a ideia de modernidade, tende a apagar as especificidades das artes para borrar os limites que os separam uns dos outros e da experiência comum. (RANCIÈRE, 2013, p. XII, tradução nossa)

Negar ou ignorar o descolamento da arte (ou de qualquer outra forma de trabalho) do entorno social é um erro cometido há muito por estudiosos desse ofício. A noção de kunstwollen de Alois Riegl, que pressupunha uma intencionalidade artística - ou uma potência artística autônoma para a forma - já foi muito questionada, pois nas ciências sociais não há espaço para postulados metafísicos, 
isto é, noções que transcendem o aspecto material ou sensível das coisas. O movimento l'art pour l'art teve um fim em si mesmo na medida em que os ideais positivistas foram perdendo espaço nas formulações epistemológicas acadêmicas, pois restou comprovado que a forma ou o estilo se modificava por conta de questões externas, pertencentes ao meio social.

Mas mesmo depois de todos esses debates, os pares do Campo do Design continuam a ensinar as questões estéticas como pertencentes apenas ao campo daqueles que atuam profissionalmente no âmbito do design, sem fazer qualquer tipo de aproximação com a História Social da Arte ou do próprio estudo da Estética. Rancière fala do ponto de partida de seu livro, Aesthesis:

Seu ponto de partida é o momento histórico, na Alemanha de Winckelmann, quando a Arte começa a ser nomeada como tal, não se fechando em alguma autonomia celestial, mas, ao contrário, dando-se um novo sujeito, o povo e um novo lugar, a história. (RANCIÈRE, 2013, p. XIII, tradução nossa)

Na citação acima fica claro o momento em que se inicia a preocupação em atrelar as formas de arte e suas características estéticas como consequências do entorno social. Evidentemente que os designers não citam os historiadores da arte, mas foram buscar na psicologia, na teoria da Gestalt, uma maneira de justificar as razões internas da forma das coisas. Outros tantos autores irão analisar os diversos movimentos de arte (e seus valores estéticos) como algo indissociável das condições históricas concretas, entre eles Arnold Hauser e Janet Wolff, no estudo das artes, e Gert Selle e Adrian Forty, no estudo do design.

“Autores mais antigos como Arnold Hauser [...] já haviam defendido a necessidade de situar a pintura e o romance em seu contexto social e econômico para que pudessem ter deles uma compreensão e uma análise adequadas" (WOLFF, 1982, p. 40). Wolff ainda afirma que J. T. Clark insistia que a relação da arte com a ideologia deve ser a principal parte de qualquer análise das obras de arte (Idem, p. 41). Ela continua mencionando que no final dos anos 1970: "Embora essa tendência seja muito minoritária nos departamentos universitários de história da arte [...], não há dúvida de que suas proporções, em volumes de trabalhos e em influência, vêm aumentando" (Idem., p. 42). Mas ao analisarmos as instâncias legitimadoras do Campo do Design nos dias de hoje, quarenta anos depois dos escritos de Wolff, é perceptível que a realidade não permite tanto otimismo: 
raramente se percebe o ensino desta ciência - a Estética - nos cursos de graduação em design. Não que a disciplina não seja ministrada, que não tenha bons profissionais, mas pelo que se pode verificar empiricamente é menosprezada em relação a sua importância na formação profissional dos jovens designers. Com o estudo aqui presente não se pretende desqualificar o trabalho do designer, mas sim promover noções que defendam que o projetista nada mais é do que um trabalhador como qualquer outro, retirando o aspecto "místico" que envolve a figura do designer.

Os significados ocultos da arte são revelados e os interesses particulares dos grupos específicos, implicitamente servidos por esses significados, tornam-se claros. Isto de modo algum significa desvalorizar as realizações artísticas enquanto obras primas da pintura, da escultura ou da literatura. Destina-se apenas a apontar que outros elementos extra estéticos estão imiscuídos no que supostamente se apresenta como julgamentos puramente estéticos. A origem e a recepção de obras tornam-se com isso mais compreensíveis pela referência às divisões sociais e suas bases econômicas. (WOLFF, 1982, p. 42)

A análise marxista dos objetos de design (objetos industriais) traz à luz alguns princípios de mercado que se "escondem" por trás da misteriosa forma da mercadoria, ou o fetichismo da mercadoria. Para Selle (1973) o valor de uso dos objetos de design só é assumido pelo produtor - contra as asserções usuais - na medida em que ainda é necessário para a venda do produto ao usuário. Um objeto que não esteja vinculado a qualquer valor de uso dificilmente seria vendido. O valor de uso, no entanto, é conferido por meio da disposição dos objetos; é um valor sensível e "estético" (nesse sentido, Selle se refere à configuração formal, ao estilo e não à dimensão filosófica) que é resgatado após o ato da compra (SELLE, 1973, p. 159). "O lado estético da mercadoria, no sentido mais amplo - aparência sensível e sentido de seu de valor de uso - é aqui separado ou apartado da coisa. Para o cumprimento do ato de compra, a aparência é tão importante - e, de fato, mais importante - quanto seu ser" (HAUG apud. SELLE, 1973, p. 159, tradução nossa).

Dessa maneira pode-se perceber que as mercadorias, frutos de processos de design, carregam em si um valor estético pré-fabricado, por assim dizer. Não é o usuário que decide o que quer comprar, mas sim as instâncias dominantes do poder socioeconômico, através de duas potentes ferramentas: a publicidade e o marketing. É dizer, o senso estético, o "gosto" é socialmente determinado, e sempre foi, pelas 
instâncias legitimadoras e que operam para a manutenção dos valores do campo. Durante uma época foi a Igreja, depois as cortes absolutistas até chegar na sociedade burguesa, na qual quem determina o gosto e a estética do objeto industrial é, em última análise, o produtor e/ou o empresário.

\begin{abstract}
Embora a vida intelectual e artística estivesse sob a tutela, durante toda a Idade Média, em grande parte do Renascimento, na França, com a vida na corte, durante todo o período clássico, de instâncias de legitimidade externas, libertou-se progressivamente, tanto econômica como socialmente, do comando da aristocracia e da Igreja, bem como de suas demandas éticas e estéticas. (BOURDIEU, 2015, p. 100)
\end{abstract}

Porém, para Bourdieu (2015) esse processo se deu no meio de outras tantas transformações. Uma delas foi a constituição de um público de consumidores cada vez mais extenso, diversificado e capaz de conceder aos artistas não apenas as condições de independência econômica, mas também "um princípio de legitimação paralelo" (Idem., Ibidem.). Depois, a constituição de um corpo de empresários e produtores de bens simbólicos que reconhecem exclusivamente certo tipo de determinações e normas que definem as condições de acesso à profissão e de participação no meio artístico. Além disso, o processo de autonomização ${ }^{23}$ da produção intelectual artística é paralelo ao surgimento de uma categoria social distinta de artistas cada vez mais inclinados a levar em conta as regras firmadas pela tradição herdada de seus predecessores, e isso vai durar enquanto o capitalismo permanecer como modo de produção econômica da sociedade industrial. Não sem gigantescas contradições, que já se pode ver com o esvaziamento do público das exposições de arte contemporânea em relação às enormes filas de museus de arte tradicional, e isto torna os artistas cada vez mais propensos a liberar sua produção de qualquer dependência social ou de seu significado, seja das censuras morais e programas estéticos da Igreja, seja de controles acadêmicos e das encomendas do poder político propenso a tomar a arte como propaganda.

\footnotetext{
${ }^{23}$ O termo "Autonomia" para Bourdieu tem um significado específico. Para ele a autonomia é sempre relativa e condição sine qua non para a existência dos "campos". É dizer, existe um habitus específico e capital específico, este último uma "arma" nas lutas internas do campo. "O privilégio concedido à 'forma' em detrimento da 'função' ('a arte pela arte') está subordinado à autonomização dos campos da arte em relação ao campo econômico e ao campo político” (MAUGER, 2016, p. 4647).
} 
Ademais, a ruptura de vínculos de dependência com um patrão ou um mecenas propicia ao artista uma liberdade formal, "sendo apenas a condição de sua submissão às leis do mercado de bens simbólicos" (BOURDIEU, 2015, p. 103). Isso acarreta no desenvolvimento de um mercado impessoal e o surgimento de numerosos compradores anônimos, propiciando ao artista uma liberdade que logo lhe revela formal. Dessa maneira, a condição da submissão do artista às leis do mercado de bens simbólicos surge através dos índices de venda e das pressões dos detentores dos instrumentos de difusão, como, por exemplo, o marchand de tableaux, os críticos de arte ou aqueles que exercem as duas funções. Assim, a aparição de um grupo anônimo burguês coincide não somente com a rejeição de cânones estéticos da burguesia, mas também com a afirmação da "autonomia absoluta do 'criador' e de sua pretensão em reconhecer apenas o receptor ideal, ou seja, um outro 'criador', capaz de mobilizar em sua compreensão das obras a disposição 'criadora' que define [...] o artista autônomo" (Idem., p. 104).

No Campo do Design as coisas parecem funcionar de modo análogo ao Campo da Arte. Designers mais "conceituados" por agentes de legitimação do campo ou fora dele possuem uma "melhor" escolha estética, ou (o que é pior) uma "nova" escolha estética (think outside the box). Aqueles, por sua vez, ganham os "troféus" do campo e se tornam, assim, agentes de legitimação. Por manterem os ideais e ideologias dos outros, se tornam agentes conservadores do campo. E, ao "tomarem a decisão" de manter as representações estéticas dogmáticas em certo objeto e/ou imagem, estão atuando como agentes políticos dentro do próprio Campo do Design.

No presente subcapítulo se procura compreender as relações entre quem postula as "regras" estéticas nos Mundos da $\operatorname{Arte}^{24}$ e os participantes deste. Considera-se importante lembrar que não se distingue aqui completamente a "arte" do design, como hegemonicamente o Campo Acadêmico insiste em fazer. "Design não é arte", afirmação recorrente nos primeiros ensinamentos ainda na graduação. Mas, ao afirmarem que design não é arte, são parciais, falham em dizer $o$ que é isso que é o design, de forma a obscurecer a própria ontologia do campo. Não há dúvida, contudo, que o design teve sua gênese no Campo da Arte e que ainda compartilha

\footnotetext{
${ }^{24}$ O termo "Mundos da Arte" é um termo cunhado por Howard Becker. Para um melhor entendimento sobre o termo e compará-lo com Campo da Arte de Bourdieu, procurar em BECKER, Howard S. Mundos da Arte. Lisboa: Livros Horizonte, 2010.
} 
de muitos pontos em comum nos seus estatutos ontológicos e epistemológicos. ${ }^{25}$ Wolff (1982) escreve sobre a suposta falta de patrocínio do artista no período moderno:

\begin{abstract}
Se essa concepção [do artista como marginal ou como adversário da ordem social] está certa quando fala do declínio das encomendas seguras e do protetor digno de confiança, ignora novas formas de patrocínio e de emprego para os artistas, muitos dos quais estão, na verdade, integrados como artista, em vários ramos da produção e da organização social capitalistas. Nas artes plásticas, essa nova situação incluiria os artistas gráficos que trabalham para a indústria, desenhistas, artistas de publicidade $[\ldots]$ etc. (WOLFF, 1982, p. 25, grifo nosso)
\end{abstract}

Pode-se perceber que a visão hegemônica da separação incondicional entre arte e design é no mínimo questionável. Rancière (2013), em sua obra Aesthesis não se propõe a explicar os porquês de analisar objetos materiais e artistas/designers que contribuíram para a construção de um pensamento estético e social que, em um primeiro momento, atuaram nas chamadas Artes Decorativas. Ele as chama, inclusive, de "Artes Sociais" (RANCIÈRE, 2013, p. 133). O autor analisa, primeiramente, os ideais do movimento Arts and Crafts, de Ruskin e Morris, e depois o trabalho e ideias de Peter Behrens, designer da empresa alemã de eletrodomésticos $A E G$, entre outros casos.

\begin{abstract}
A arte social não é uma arte para o povo; é arte a serviço de fins determinados pela sociedade. Mas essa definição pode ser lida de trás para frente. A arte social não é a arte de qualquer sociedade: é a arte de uma sociedade onde "os homens vivem como homens", onde se constrói para abrigar e expressar a vida, e não para impor uma relação espelhada entre a distinção de uma classe e uma distinção de arte (Idem., p. 135).
\end{abstract}

Nesse contexto, julga-se sensato inserir o design nos "Mundos da arte", de Howard Becker (2010). Para o autor, a função dos estetas estudarem os postulados e argumentos para classificar as atividades nas categorias de belo, arte, belas-artes e não artes é a de fazer juízo para determinar a reputação das “obras” e dos artistas que as realizam. Defende que, dessa forma, a estética se apresenta como uma

\footnotetext{
${ }^{25}$ Uma prova prática deste argumento seria que o autor do presente artigo, ao cursar Design Gráfico, na Universidade Federal de Pelotas, teve todo o primeiro ano letivo com quase a totalidade das disciplinas iguais no curso de Artes.
} 
“atividade", e não como uma "doutrina" (BECKER, 2010, p. 127). É dizer, existem agentes que legitimam esta ou aquela escolha estética, construindo sistemas estéticos que possuem validade lógica e filosófica, e que "a criação desses sistemas pode tornar-se uma verdadeira indústria em si mesma" (Idem., Ibidem.).

Pode-se formular um exemplo concreto dentro do Campo do Design e de suas instâncias legitimadoras: se um designer gráfico se inscrever em um concurso de cartazes para um evento cultural ele certamente irá buscar suas referências dentro do sistema estético desse contexto. E o que mais bem realizar esta tarefa (a escolha da tipografia, das cores, das texturas e das imagens condizentes com o sistema estético hegemônico) certamente será o vencedor do hipotético concurso.

Uma formulação estética demostra que, quando baseada em argumentos suficientemente gerais e convincentes, as atividades de determinados membros de um mundo da arte são da mesma ordem que outras atividades que já usufruem dos privilégios ligados à 'arte' (Idem., p. 128).

Além disso, um sistema estético "coerente" contribui para a permanência dos valores de certo tipo de prática "artística" e, assim, para a homogeneidade da prática. Designers que mantêm aspectos estéticos consagrados ajudam a reproduzir tais aspectos por meio de outros designers que tenham a mesma posição sobre o valor desses projetos. Valores estáveis estabilizam também outras variáveis, como os preços, a reputação dos designers, o prestígio dentro e fora de seu campo e, principalmente, o que é um "bom design", ou seja, o que vai gerar maior lucro para o sistema.

\section{Conclusão do Capítulo 4}

Conforme o estudo realizado nesse capítulo, se percebe que com a passagem do Ancien Régime para a República ou para as formas e maneiras da Idade Moderna surge, além de uma sociedade com "novos" valores, um novo tipo de agente social moderno, qual seja o homem individualizado, conforme descrito no primeiro capítulo da presente dissertação. Isso se dá, num primeiro momento, em razão das mudanças de poder, ou seja, a troca de regimes absolutistas para a sociedade burguesa. É dizer, através de um novo sistema político no qual a burguesia controla o modo de produção, que vem a se tornar o industrial, aparece também a divisão do 
trabalho e, consequentemente, maior afirmação do sujeito individualizado, que acredita que suas subjetividades são únicas e que suas criações são individuais, autônomas e autoritárias.

Esses fatos sócio históricos, que se constroem durante pelo menos dois séculos, o XVIII e o XIX, transformam de maneira radical todo o trabalho humano, tendo profundas consequências em todos os campos do saber e do labor. No Campo da Arte não foi diferente, e a forma de atuar dentro dele também não. Com o fim do Mecenato e dos patrocínios, seja através da Igreja, seja através das cortes, o artista muda a forma de se relacionar socialmente, passando a depender de outras instâncias para vender sua força de trabalho. Dizer que o artista caiu na marginalidade, e que por causa disso se transformou num indivíduo solitário, melancólico e "gênio" por causa das mudanças ditas acima é uma noção romântica, ultrapassada e carismática. O que ocorreu foi, como visto, um câmbio na forma de atuar, no qual o artista passou a depender, assim como toda forma de trabalho, da indústria e dos agentes dominantes, qual seja o capitalista, o produtor, o empresário. Assim, muitos migraram para trabalhar na indústria, e uma das profissões que surgem com essa migração é a do design.

No período supracitado surge também uma nova doutrina, a da Estética. Antes desse estudo analisar a arte e o belo, analisava primeiramente a relação ente o material e o imaterial. Acontece que, como dito anteriormente, o imaterial, o metafísico, o sensivel não é objeto de estudo da sociologia, que pretende entender os fenômenos sociológicos através de estudos desta realidade concreta que são as demandas sociais. Desta forma, o presente capítulo procurou analisar as relações sociais que surgem, dentro do Campo da Arte e do Campo do Design, da estética e com as escolhas políticas ou ideológicas que ela promove.

A construção de objetos e imagens são escolhas políticas, isto é, são os agentes sociais dominantes, que têm por função promover a manutenção dos valores dos campos, que "optam" por uma forma ou outra. E que, através de meios de violência simbólica ou inculcação (como por exemplo as ferramentas da publicidade e do marketing) "convencem" a sociedade de que os artistas ou designers são seres "dotados" de uma capacidade criadora de formas, uma competência estética, que forma gostos e preferências. É claro que todos possuem suas subjetividades e idiossincrasias, mas o que decide o misterioso da forma ou o 
fetiche da mercadoria (no caso do trabalho de arte, a "aura") não são essas características individuais citadas.

A arte e o design (que, como viu-se, não são indissociáveis) se parecem desta ou daquela maneira não pela escolha individual do artista/designer "gênio" que cria de maneira solitária em seu ateliê ou estúdio, mas através de construções sociais que se formam nas instâncias de poder. É dizer, o artista e o designer têm muito pouco (ou nenhum) poder na tomada de decisão de como vai se parecer um trabalho seu. É a encomenda, através de agentes como o marchand de tableaux, e o briefing, através dos produtores e empresários, que acaba por decidir qual será a melhor forma (estilo) de representar um objeto ou uma imagem gráfica. E esta forma será, invariavelmente, a que vender mais.

Assim sendo, conclui-se que o mito do gosto ou da escolha estética único e individual, que nasce de um ser dotado de capacidades especiais e inexplicáveis, não se sustenta no modo de produção vigente, e que essas noções são, além de românticas e ultrapassadas, reproduzidas larga e amplamente nas instâncias de legitimação que consagram isto que é arte e design, pois é interessante para que os agentes conservadores dos campos manter o status quo classista e burguês. 


\section{CRÍTICA DO DESIGN AUTORAL}

Já foi formulada a questão de que existem poucas publicações científicas sobre isto que se denomina de design autoral. Tais publicações foram escritas em sua maioria na década de 1990, quando o presente tema era comum principalmente nos Estados Unidos da América, ainda que este fenômeno permanecesse polêmico e sujeito a mal-entendidos (POYNOR, 2010, p. 121).

$\mathrm{Na}$ verdade, apenas dois textos são apresentados pelos pares do campo como se esses estudos eventualmente tivessem encerrado a questão da autoria gráfica. $\mathrm{O}$ designer e escritor americano Michael Rock inaugurou a discussão sobra a noção do designer como autor em um artigo escrito para a revista Eye Magazine, em 1996, denominado "O designer como autor" e, depois, em 2003, o também designer e escritor - desta vez americano - Rick Poynor, escreveu um capítulo inteiro (denominado "Autoria”) em seu livro "Abaixo as regras: design gráfico e pósmodernismo". 26

Tudo levava a crer que, como dito anteriormente, tais estudos haviam encerrado as futuras discussões sobre esse assunto por se basearem (principalmente no texto de Rock) em importantes trabalhos de Barthes e Foucault exatamente sobre o problema da autoria. Acontece que o que se pretende não é examinar a autoria gráfica como se as imagens fossem “um sistema de signos” (BURKE, 2017, p. 258), o que se tornou comum através de enfoques ${ }^{27}$ estruturalistas, também conhecidos como "semióticos" ou " semiológicos". O que se busca agora é realizar uma crítica sobre autoria enquanto instrumento e manutenção de poder nas mãos de agentes conservadores do Campo do Design através de uma análise histórica e concreta desta prática social que é o trabalho do designer.

\footnotetext{
${ }^{26}$ Ambos os estudos foram lidos pelo autor desta dissertação tanto na eletiva de graduação da Universidade Federal de Pelotas quanto na pós-graduação da mesma instituição.

${ }^{27}$ Utiliza-se aqui o termo "enfoque", e não método, tal qual sugere Peter Burke. "Eu os chamo de 'enfoques' e não de 'métodos' pelo fato de que eles representam não tanto procedimentos novos de pesquisa quanto novos interesses e novas perspectivas” (BURKE, 2017, p. 257).
} 
No presente capítulo se examinará os dois textos, com o intuito de fazer uma análise crítica de cada um deles. Desta forma, se questionará as propostas enunciadas pelos autores de que existe, sim, um design autoral, apesar de que os próprios autores, por vezes e timidamente, questionem a possibilidade da existência de um design autoral de fato.

\section{1. Uma apresentação à noção hegemônica da autoria no Campo do Design}

$\mathrm{O}$ zeitgeist vigente, ou desde que se convencionou denominar a cultura da época em que vivemos de pós-moderna, noção ${ }^{28}$ que considera-se nesta dissertação como equivocada, instituiu uma discussão a respeito da noção de design autoral fora das análises ou enfoques estruturalistas de Foucault e Barthes. Acontece que tais discussões se basearam no debate da autoria principalmente no campo da literatura e passavam longe dos debates sobre artes ou design gráfico. "A análise estrutural é certamente mais inovadora - e mais chocante - no caso da narrativa literária do que no caso das imagens" (BURKE, 2017, p. 263). Desta forma, os designers, por acreditarem que a imagem, assim como o texto é um sistema de signos e que podem ser "lidos", tomaram para si os resultados dos debates.

A chamada "morte do autor", proposta de forma mais sucinta por Roland Barthes em um ensaio de 1968 com esse nome, está intimamente ligada ao nascimento da teoria crítica, especialmente a teoria baseada na resposta e interpretação do leitor, em vez da intencionalidade. Michel Foucault usou a pergunta retórica 'O que é um autor?' em 1969 como o título de um influente ensaio que, em resposta a Barthes, descreve as características básicas e funções do autor e os problemas

${ }^{28}$ Ver particularmente CONTINO, Joana Martins et CIPINIUK, Alberto. Ideologia, divisão capitalista do trabalho e papel social do designer: um estudo sobre a produção de materialidade no design de moda In.: Revista Moda Palavra, volume 10, número 19, 2017. Trabalho apresentado no $12^{\circ}$ Congresso Brasileiro de Pesquisa e Desenvolvimento em Design (P\&D Design), novembro de 2016. Constando nos Anais, volume 2, número 9. https://www.proceedings.blucher.com.br/article-details/ideologia-diviso-capitalista-do-trabalho-epapel-social-do-designer-um-estudo-sobre-a-produo-de-materialidade-no-design-de-moda-24299. Acesso em: 20 out. 2019. 
associados às ideias convencionais de autoria e origem. (ROCK, 1996, tradução nossa)

Caso o leitor tenha tido a ocasião de ler com atenção esse parágrafo já surgem, pelo menos, dois problemas: o primeiro é a necessidade de acreditar que se vive num paradigma pós-moderno, noção teórica equivocada, mas reproduzida largamente pelos pares do campo e que se despreza, aqui, explicitamente; e o segundo é afirmar que a imagem é apenas um suporte para a transmissão de um sistema de signos que pode ser "lido" assim como o texto. Não é pretendido na presente dissertação analisar essas noções, mas merece ser dito que nenhuma dessas duas afirmações são unânimes entre os estudiosos tanto da cultura quanto da imagem. Mas é importante ressaltar que tanto Rock quanto Poynor localizam o leitor historicamente nesse enigmático e obscuro período classificado de pósmoderno e entendem as imagens como a materialização de uma linguagem.

Não é o pretendido aqui fazer uma profunda análise acerca dos termos "pósmoderno" ou "pós-industrial"29, mas julga-se necessário situar os porquês de não concordar-se com tais termos. Daniel Bell (1977) é quem cunha o termo "sociedade pós-industrial",

[...] e as teorias correlatas a essa nomenclatura procuram demonstrar que haveria uma nova forma social que não obedeceria às leis do capitalismo clássico, tais como a primazia da produção industrial e a onipresença da luta de classes. (CONTINO et alii, 2017, p. 42)

Defende-se outra posição, a de que estamos vivenciando o capitalismo tardio, e que esse termo se refere apenas a uma nova fase do desenvolvimento capitalista que ainda mantém as leis básicas, “como o papel central do valortrabalho, a tendência à concentração e centralização de capitais, entre outras" (Idem., Ibidem).

Isto posto, o que já declara uma série de problemas quanto ao que esses dois pesquisadores propuseram, é importante ressaltar que também não é pretendido aqui analisar os textos sob a ótica estruturalista, como já foi dito, mas sim afeito à ótica do que, pela falta de uma melhor classificação, se denomina reflexão crítica. Julga-se importante, também, estudar os escritos de autores que formularam a

\footnotetext{
${ }^{29}$ Em geral os dois termos são considerados sinônimos, visto que boa parte dos pesquisadores afirma que a sociedade industrial nada mais é do que o auge da sociedade dita moderna, pois o que caracteriza o a sociedade moderna é seu modo de produção, o capitalismo, que tem como maior característica a total industrialização dos bens de consumo (mercadorias) e a forma de obter maisvalor através das trocas simbólicas entre as mercadorias.
} 
Teoria Social da Arte (por haver entre Campo da Arte e o Campo do Design uma porosidade, uma larga e cinzenta fronteira de grandes indefinições) para, dessa forma, ajudar para a construção de uma Teoria Social do Design.

Rock (1996) inicia seu artigo sustentando que a autoria gráfica é tida como certa por teóricos do campo e que também está ganhando espaço na prática do design. Importante ressaltar que, para ele, a ideia recebeu pouco exame para que se sustente (ROCK, 1996). Já Poynor (2010) relata que a questão da autoria é um dos conceitos-chave no período pós-moderno, mas que é, também, uma das ideias mais problemáticas (POYNOR, 2010, p.118). "Conforme algumas correntes da teoria crítica, a própria noção de um 'autor' como fonte autoritária de validação para a obra cultural é ultrapassada, retrógada e reacionária" (Idem., Ibidem). E é justamente esta noção de autoria que se pretende criticar no presente trabalho.

O que seriam ou quais seriam essas fontes autoritárias que legitimaram essa visão ultrapassada e reacionária senão os agentes legitimadores do Campo do Design, agentes esses que legitimam as noções do campo de forma a conservar (agentes conservadores) ideias e ideais retrógrados? No capítulo intitulado "A Violência Simbólica e o Fetichismo da Mercadoria - a manutenção do pensamento acrítico no Campo do Design" já houve a discussão sobre os pensamentos de Pierre Bourdieu sobre tais termos e as formas de Violência Simbólica que mantém certos agentes como conservadores do campo. No texto de Rock (1996) o autor também menciona ideias semelhantes:

Mas as teorias de autoria também servem como estratégias legitimadoras, e as aspirações autoritárias podem acabar reforçando certas noções conservadoras de produção e subjetividade do design - ideias que vão contra as recentes tentativas críticas de derrubar a percepção do design como baseadas no brilhantismo individual (ROCK, 1996, tradução nossa).

Se Barthes afirmava que o autor está morto e Foucault questionava se fazia diferença quem estava falando, isto é, quem era o sujeito enunciador do discurso, o que se pretende neste trabalho é entender quem está se beneficiando para que o mito da autoria gráfica se sustente, seja no meio acadêmico, seja no mercado de trabalho onde os profissionais do Campo do Design atuam. Uma coisa é certa: nem Barthes nem Foucault encerraram a questão carismática da autoria no Campo da Arte ou no Campo do Design. Tanto entre os pares do Campo do Design quanto os de fora 
dele, a noção individual da autoria, cada vez mais, vem se perpetuando em nossa sociedade. Prova disso é a enorme gama de "autores heróis", isto é, profissionais que se destacam em seus campos por serem julgados como indivíduos especiais, criadores autônomos que vêm se multiplicando na contemporaneidade em diversos campos.

Ambos os autores listam alguns designers autorais e, não coincidentemente, vários se repetem nas duas listas:

A lista provavelmente incluiria Fabian Baron, Tibor Kalman, David Carson, Neville Brody, Edward Fella, Anthon Beeke, Pierre Bernard e Gert Dunbar, Tadanoori Yokoo, Oliver Vaughn, Rick Valincenti, abril Greiman, Jan van Toorn, Wolfgang Weingart e muitos outros. (ROCK, 1996, tradução nossa)

Alguns designers gráficos - Neville Brody, David Carson, Tibor Kalman - atraíram a atenção da mídia de massa, na qual eram apresentados como importantes formadores da cultura visual contemporânea. (POYNOR, 2010, p. 119)

É muito provável que para qualquer iniciado no Campo do Design (por exemplo, para qualquer estudante que esteja cursando a sua graduação em design) seja fácil conhecer e citar pelo menos alguns desses nomes, mas é importante ressaltar que se está analisando apenas o campo do Design Gráfico. Certamente no Campo de Design de Moda, por exemplo, existem muitos outros "designers autores”. E parece ser assim nos diversos Mundos da Arte, tal como na música, no teatro e no cinema.

Esse último campo - o do cinema - propôs uma teoria do Auteur, criada em 1954 pelo crítico de cinema francês François Truffaut e defendida principalmente pelo crítico americano Andrew Sarris (ROCK, 1996). A exemplo do que ocorre nos outros "mundos da arte", a proposta de Sarris postulava que o diretor de cinema deveria preencher três requisitos para entrar para o seleto "time" de artistas/autores. O diretor deveria demonstrar perícia técnica, possuir uma assinatura estilística notável em seus filmes e uma consistência de visão e significado interior (Idem., Ibidem.).

Parece sensato entender que, em uma sociedade industrial, perícia técnica deva ser condição sine qua non na prática de qualquer trabalho e não apenas uma exclusividade para os cineastas. Em relação às assinaturas estilísticas defende-se neste trabalho que as mesmas são escolhas coletivas e políticas, ou seja, pertencem 
a um dado momento histórico concreto, com características sociais e econômicas concretas, ou como explica Janet Wolff: “Os significados ocultos da arte são revelados e os interesses particulares de grupos específicos, implicitamente servidos por esses significados, tornam-se claros" (WOLFF, 1982, p. 42). Isto é, existem interesses de cunho político para que os filmes (e pinturas, e esculturas, e designs) se pareçam como se parecem, e isto diz respeito a uma disposição social concreta ou habitus que é inculcado coercitivamente em nossa sociedade, através de Violência Simbólica ${ }^{30}$, como se o gosto fosse uma questão pessoal, pertencente à subjetividade do indivíduo. E, por fim, uma “consistência de visão e significado interior" parece ser uma ideia que, talvez, o campo da psicanálise poderia explicar melhor, pois a subjetividade e o individualismo não fazem sentido neste exame sociológico. Sarris (apud. ROCK, 1996) tentou descrever o significado disto que é "visão interior", recorrendo à "diferença intangível entre uma personalidade e outra", e afirmou sobre essa intangibilidade que "não posso dizer o que é, mas eu sei disso quando vejo". Fica claro que este é mais um caso de je ne sais quoi, ou seja, uma noção baseada na crença, algo que não se defende com argumentos a favor ou contra, apenas acredita-se.

Acontece que é muito comum (e perigoso) associar uma forma de trabalho com outra, e foi exatamente isto que Michael Rock fez em seu artigo:

\begin{abstract}
A coisa interessante sobre a teoria do autor é que os teóricos do cinema, como os designers, tiveram que construir a noção do autor como um meio de elevar o que era considerado baixo entretenimento ao platô da arte. Os paralelos entre a direção do filme e a prática do design são impressionantes. Como o diretor de cinema, o diretor de arte ou designer é muitas vezes distanciado de seu material e trabalha de forma colaborativa nele, dirigindo a atividade de várias outras pessoas criativas. Além disso, ao longo de uma carreira, tanto o diretor de cinema quanto o designer trabalham em vários projetos diferentes, com diferentes níveis de potencial criativo. (ROCK, 1996, tradução nossa)
\end{abstract}

Neste trabalho julga-se que não é interessante aproximar o Campo do Cinema ao Campo do Design, visto que o que se propõe, também, é justamente uma definição mais concreta disto que é o design e uma contribuição ontológica e

\footnotetext{
${ }^{30}$ Ver acima o capítulo "A Violência Simbólica e o Fetichismo da Mercadoria - a manutenção do pensamento acrítico no Campo do Design", p. 33.
} 
epistemológica para o campo. Ademais, propõe-se que o design não procure ser elevado ao platô da arte, pelo contrário, defende-se que existe uma possibilidade para que se encontre a sua raison d'être, pois apesar de já termos visto que o Campo do Design se originou do Campo da Arte, julga-se que existe uma singularidade para nossa prática profissional. A prática profissional do design gráfico possui inúmeras diferenças sistemáticas em relação ao Campo do Cinema, e pode ser danoso para o Campo do Design, já tão confundido e confundível, tomar para si propostas teóricas de outros campos. Ainda mais se a teoria não é muito clara. Para Rock, a intangibilidade do "significado interior" foi uma das razões pelas quais a teoria do autor caiu em desgraça. "Mas enquanto a teoria é ultrapassada, seu efeito ainda está conosco: o diretor até hoje está no centro de nossa percepção da estrutura do filme" (ROCK, 1996, tradução nossa). Seria esse o único motivo para que o diretor permaneça como um gênio criativo? Sustentamos exatamente o contrário. O cinema, assim como a prática do design, está localizado no nosso modo de produção em massa e os filmes, assim como objetos de design, são mercadorias. Portanto, numa sociedade em que o que se visa é a produção do mais-valor, é interessante para os agentes de legitimação que existam autores gênios/heróis, para que desta maneira as mercadorias sejam consumidas cada vez mais, reforçando seus fetichismos e de seu valor de troca simbólica.

\section{Categorizações: tentativas de legitimar a autoria no Campo do Design.}

$\mathrm{Na}$ tentativa de legitimar formas de design autoral, Rock (1996) parece criar categorias que, segundo suas próprias convicções, podem ser modelos de autoria gráfica. A intenção é a de analisar tais modelos e fazer um questionamento acerca dos mesmos.

As duas primeiras categorias apresentadas e que "legitimariam" o designer como autor são o livro de artista e o design ativista. "O livro de artista oferece uma maneira de autoria de design no qual a forma foi completamente exorcizada" (ROCK, 1996, tradução nossa). Não parece muito claro o que Rock desejou explicar empregando o termo exorcizar. Como seria possível exorcizar a função social em um projeto de design? Exorcizar é o mesmo que expulsar demônios ou espíritos 
malignos de alguém e não parece muito claro o que se estaria expulsando com a produção do livro de artista. Ou melhor, não fica claro se, depois de exorcizar a função social ou a finalidade desse objeto que materializa a subjetividade do indivíduo criador, o livro de artista continuaria a ser um objeto de design. Pergunta se não seria necessário afirmar que a forma e a função não deveriam caminhar juntas, afinal não seriam elas cânones complementares para a prática profissional do designer gráfico? Mas o autor vai além: "O livro de artista, em geral, é concreto, auto referencial e permite uma série de experiências visuais sem o ônus de cumprir tarefas mundanas" (Idem., Ibidem. Tradução nossa, grifo nosso). Parece ser que Rock está tratando de objetos mais aproximados do Campo da Arte, não apenas porque emprega o termo "livro de artista", mas visto que não existe função de uso prático nestas mercadorias. Ele considera o livro de artista como se fosse um objeto autônomo ou independente do seu entorno social, o mundo da sociedade industrial. Defende a passadista noção da arte pela arte, da arte como algo gratuito, uma finalidade sem fim que serve apenas para que o observador possa fruir ou se deleitar com aquilo que vê. E a autorreferência é mais uma maneira de colocar na figura do designer esta "aura" que envolve os artistas idealizados. A autorreferência é uma maneira de consagrar a noção romântica e idealista do artista como gênio da raça, antena do futuro, e esta prática é antiga no Campo da Arte, anterior ao próprio movimento romântico.

Rembrandt começou pintando autorretratos para o ateliê, depois para ele mesmo e para o mercado. As duas últimas opções ele tratou como uma coisa só. Dado que a arte do autorretrato fora para ele, inicialmente, uma prática de estúdio e não uma apresentação do artista para o mundo, Rembrandt conseguiu transformar o autorretratar-se numa nova imagem de si. Retratar a si mesmo no ato de pintar e conceber esse autorretratar-se em benefício próprio era um ato inovador. Tal fato merece ser sublinhado, porque nosso conhecimento da pintura de Van Gogh e de Cézanne nos habituou a situar o autorretrato no centro da arte de um pintor e a concluir que nenhuma invenção era exigida. (ALPERS, 2010, p. 305-306)

Através a citação acima, Alpers (2010) demonstrou que a prática de se autorreferenciar foi uma prática que já existia há muito (pelo menos desde o século XVII) como forma de o artista se beneficiar tanto de capital financeiro como de capital simbólico, uma vez que Rembrandt imprimiu na sua obra suas “características próprias", seja na forma de retratar uma imagem, um “estilo", um 
ideal entre tantas outras possibilidades. Desta maneira, mais uma vez confirma-se que se tenta elevar o designer ao panteão dos artistas/autores, individuais e autoritários. Acontece que, sem a dimensão funcional, isto é, se deixarmos de considerar o valor de uso dos objetos e se levar em conta apenas o seu valor de troca simbólica, ele passa a ser apenas uma mercadoria. Desmonta-se aqui o fetiche da mercadoria, pois embora os partidários do modo de produção capitalista defendam que os objetos possuam um valor de uso, que servem para isso ou aquilo, sabem que isso não é verdade, pois desejam apenas trocá-lo por dinheiro e produzir maisvalor. E vale à pena reforçar que atribuir valor de uso a um objeto é sim o "ônus de cumprir tarefas mundanas", afinal, não existem tarefas que não sejam "mundanas", isto é, que não pertençam ao mundo dos homens.

O próprio Rock escreveu sobre design ativista como auto motivado e auto escrito, além de ter uma agenda política clara (ROCK, 1996). Acontece que o trabalho político a que Rock se refere é colaborativo, logo não pode ser de cunho individual. "De quem é a voz que está falando? Não um indivíduo, mas algum tipo de comunidade unificada. Este trabalho está aberto para interpretação ou seu ponto é a transmissão brutal de uma mensagem específica"? (Idem., Ibidem.). Até porque considerar o ativismo político como "uma espécie de livre expressão pessoal" (Idem., Ibidem.) parece ser paradoxal, pois um ato colaborativo, especialmente uma ação política, não pode, por definição, ser de "livre expressão individual”. Ademais, para Marcuse (apud. WOLFF, 1982), em uma abordagem neomarxista, por assim dizer, as artes até podem, de alguma maneira, expressar e retratar desigualdades sociais, mas, quando são traduzidas para o nível estético, agem apenas de maneira catártica, afirmando as relações sociais existentes (WOLFF, 1982, p. 100). É dizer, as expressões artísticas possuem uma autonomia relativa em relação ao meio social em que elas ocorrem, nas quais muitas vezes o artista deve sacrificar a sua vontade de traduzir o novo para atender à tradição, aquilo que antigas práticas vinham realizando. E se os artistas agirem tal como desejavam as vanguardas artísticas do início do século XX, defendendo uma oposição radical entre aquilo que se produzia e aquilo que agora se propunha (que de certo modo se institucionalizaram nisso que hoje chamamos de arte contemporânea), as pessoas ou o público simplesmente não compreendem o que eles desejavam comunicar, tal o radicalismo de sua proposição. Muitas vezes, os ativismos políticos através da arte desestimulam o pensamento crítico e "pacificam o desejo de rebelião" (MARCUSE apud. WOLFF, 1982, p. 
100). Marcuse desenvolveu este pensamento num ensaio intitulado de "Caráter afirmativo da cultura", e escreveu que tal caráter promovia a aceitação política e sugeria soluções falsas de "conflitos e harmonias artificiais na esfera estética" (Idem., Ibidem.). Julga-se que é preciso ter cuidado quando se emprega a arte para tratar da política. A arte não imita a vida, nem a vida imita a arte. A maior parte das vezes a arte imita a própria arte, segue a tradição da própria arte. ${ }^{31}$

Tanto para Rock quanto para Poynor a fórmula mais representativa de autoria gráfica é o exemplo de autores como pessoas dotadas de várias competências. Aqueles que além de executarem o trabalho do designer propriamente dito, escrevem e publicam material sobre design, acumulando simultaneamente as funções que normalmente seriam exercidas de modo separado por outras pessoas. Poynor apresenta o exemplo de Ellen Lupton, que além de ter criado exposições sobre design (mais um exemplo do design ocupando o "espaço" da arte) nas quais ela fazia a pesquisa, criava os trabalhos de design gráfico propriamente ditos, editorava, era designer da exposição e designer do catálogo (POYNOR, 2010, p. 123). Para Rock, o exemplo de Lupton vale para Joseph Muller-Brockmann, Paul Rand, Erik Spiekermann, William Morris e, também, para a própria Ellen Lupton (ROCK, 1996). Segundo o autor, "a maioria divide as atividades em três ações: edição, redação e design" (Idem., Ibidem., Tradução nossa). Esse pensamento apenas corrobora para a hipótese central desta dissertação: que toda forma de trabalho é colaborativa, pois é humanamente impossível realizar essas três etapas sem coletividade, sem que outros autores, editores e designers participem desse circuito. "Ellen Lupton e J. Abbot Miller construíram quase que sozinhos a nova abordagem crítica do design gráfico [...]" (Idem., Ibidem. Tradução nossa, grifo nosso). "Quase que sozinhos” é dizer que não construíram sozinhos, e sim em colaboração com outros editores, redatores e designers menos famosos, além de toda a massa crítica de outros autores que vieram contribuindo para a formação do conhecimento no Campo do Design.

\footnotetext{
31 Aqui se faz referência à arte de modo geral, mas evidentemente que alguns pares do campo poderão nos contestar afirmando que houve uma ruptura na tradição do Campo da Arte depois das vanguardas artísticas do início do século XX, contudo, terão de concordar que logo depois esse movimento criou suas próprias regras, a sua tradição e ai de quem ouse transgredi-las, pois os artistas contemporâneos são ferozes defensores de sua contemporaneidade, tanto quanto foram os membros das academias depois de sua criação na França em 1648.
} 
Outro problema a respeito dessa noção é algo que foi sugerido logo na introdução deste capítulo: designers que se apropriaram das ideias estruturalistas para que, na disputa entre a palavra e a imagem, para saber quem é mais eficaz em termos de comunicação, elevassem a imagem ao nível da linguagem. "Assim como a linguagem é um grid que decompõe as experiências em signos que podem ser repetidos - de acordo com a leitura que Lupton fez de Saussure - o próprio grid é também uma forma de linguagem" (POYNOR, 2010, p. 124). Importante notar que Lupton vai além: agora até mesmo o grid é uma forma de linguagem.

\begin{abstract}
A educação em arte moderna muitas vezes desestimula os designers gráficos e se envolverem ativamente no processo de escrita [...] Em vez disso, o designer gráfico poderia por ser concebido como um profissional da linguagem equipado para iniciar projetos ativamente - tanto pela autoria literal dos textos quanto pela elaboração, direcionamento ou rompimento de seu significado. O designer gráfico "escreve" documentos verbais/visuais por meio de composição, dimensionamento, estrutura e edição de imagens e textos. (LUPTON apud. POYNOR, 2010, p. 124)
\end{abstract}

O desmonte crítico sobre a "autoria literal" já foi feito, como visto antes, por Barthes e Foucault, e não se pretende analisar nesta dissertação aspectos literários. Deixemos essa tarefa para os críticos da literatura. O que se julga importante analisar aqui é a noção de que o designer "escreve" através dos chamados fundamentos da "linguagem visual". 32

Para Cipiniuk (2014) os linguistas e semiólogos utilizam as imagens de modo muito particular, reduzem as imagens apenas a signos. Segundo o autor, para Sausurre a linguística seria parte de uma ciência maior, e esta ciência seria a semiologia. E que esta ciência deveria ser uma ciência universal, para ser aplicada a todos os signos. Desta maneira, se suas teorias fossem válidas para a língua verbal, serviria, também, para qualquer outro tipo de sistema de signos.

\footnotetext{
32 "Fundamentos da Linguagem Visual" foi uma disciplina cursada pelo autor deste trabalho em dois semestres, no qual o livro "Novos fundamentos do design", de Ellen Lupton (2008) foi o principal aporte teórico. Lupton faz uma tentativa de desdobrar algumas características de composição (como ritmo e equilíbrio, escala, textura, cor, figura/fundo entre tantas outras) como se fizessem parte de uma espécie de "alfabeto" visual. Ocorre que esses elementos gráficos carecem de algo que as imagens não possuem: a flexibilização dos tempos verbais. Todos esses elementos só existem no tempo presente, o mesmo que os espectadores empregam para ver o que veem.
} 
Saussure ungiu com santos óleos o elemento chave do formalismo empregado na antropologia estrutural, que também é largamente utilizado nas ciências sociais para consagrar o viés idealista de análise, que justifica isso que se chama capacidade de criar ou conceber coisas novas por designers, artistas, músicos e literatos em geral. (CIPINIUK, 2014, p. 95)

Cipiniuk afirma ainda que este modo de pensar - tomar a imagem apenas como signo - é a concretização de uma forma ideológica, pois frequentemente ela se aplica aos elementos gráficos, mas muitas vezes não. Ademais, os colocam fora de sua situação histórica concreta, levando o pesquisador a considerar que tal arranjo formal é espontâneo, podendo ocorrer em qualquer período histórico e em qualquer lugar do planeta. Mas dizer que a configuração em geral é resultado de uma metodologia fixa que pode ser deduzida de um axioma teórico é "um equívoco incomensurável" (Idem., Ibidem.).

Rock, em seu penúltimo modelo teórico que poderia indicar um nível de autoria gráfica seria o de "dar sentido a um mar de material e construir uma narrativa". O exemplo utilizado tanto em Rock quanto em Poynor é o polêmico (para dizer o mínimo) exemplo do designer Bruce Mau e seu trabalho com o arquiteto Rem Koolhaas. Bruce Mau colaborou com o arquiteto holandês no livro $S, M, L, X L$, de 1995. A obra, que possui 1.344 páginas, é dividida em quatro seções. O conteúdo é de Koolhaas: o texto, o conjunto da obra e a carreira são dele. "Mas a visualização de Mau concede a esse intimidante volume de material uma presença estrutural que excede em muito a de uma monografia qualquer" (POYNOR, 2010, p. 123). Não parece lógico, contudo, reclamar autoria por causa do volume de conteúdo projetado, inclusive existem obras literárias muito maiores do que essa, mas como os autores não são "estrelas" no campo gráfico, permanecem no anonimato.

\footnotetext{
A nova abordagem substitui a divisão de trabalho pela síntese, clientes e contratações por colaboradores e parceiros, executar tarefas por negociar espaços, produção máxima por feedback máximo, e forma aplicada ao conteúdo por forma e conteúdo simultaneamente evoluindo e enriquecendo um ao outro [...]. Não temos certeza se esse novo modo de trabalho significa o fim do design, se significa que designers se tornem autores, se significa que autores se tornem designers, ou todas as três. (MAU apud. POYNOR, 2010, p. 122)
}

Uma "nova abordagem"? Divisão de trabalho, colaboradores e parceiros, forma e conteúdo "simultaneamente evoluindo e enriquecendo um ao outro"? Nem 
aqui Mau é "gênio criativo", mas sim autor carismático que, através de ideias antigas transmutadas em ideias novas acabam por engendrar as ideias do campo. Tudo indica que designers estão fazendo o mesmo que fazem com as mercadorias, agora com a teoria do design. Mau camufla ideias antigas como ideias novas, "enfeitiçando" teorias já há muito discutidas no campo. Esse "modo de trabalho" não é novo, nem significa o fim do design, nem significa que designers se tornem autores e nem que autores se tornem designers. Muito menos todas as três opções.

No livro "Design and crime", o crítico Hal Foster (2003) traz à tona as ideias infantis de Bruce Mau a respeito disto que é design, e afirma que, "como Deleuze e Guattari, sem falar em Marx, nos ensinaram há muito tempo, essa desterritorialização é o caminho do capital” (FOSTER, 2003, p. 24).

Mau desenvolve os antigos insights sobre a mídia de Marshall McLuhan, mas, como seu compatriota, parece confuso em seu papel ele é um crítico cultural, um guru futurista ou um consultor corporativo? Em futurologia de mídia, um termo crítico hoje pode se tornar uma frase cativante amanhã e um clichê (ou marca) no dia seguinte. Em um movimento irônico, Koolhaas agora copia suas frases cativantes, como se reconhecesse esse encanto comercial de conceitos críticos na página. No entanto, para toda a linguagem situacionista de designers contemporâneos como Mau, eles não "detestam" muito; Mais do que críticos do espetáculo, eles são surfistas (o que é de fato uma figura favorita em seus discursos), com "o status do artista [e] o pagamento de um empresário". "Então, onde meu trabalho se encaixa"?, Pergunta Mau. "Qual é a minha relação com esse monstro feliz e sorridente? Onde está a liberdade neste regime? Eu sigo Timothy Leary e 'sintonizo, ligo, abandono?' Quais ações posso cometer que não podem ser absorvidas? Posso superar o desempenho do sistema? Posso ganhar"? Ele está brincando? (FOSTER, 2003, p. 24-25, tradução nossa)

Foster desmantela a ideia de Mau, que queria "ser um artista, mas com o salário de um empreendedor”. Mas isso não foi o suficiente para que a ideia fosse evitada, e o que mais se percebe no Campo do Design são profissionais que almejam essa mesma distinção social de caráter simbólico, na qual o designer é tratado como artista romantizado, um príncipe do espírito, mas que também é um grande homem de negócios e que acumula capital financeiro. Percebe-se novamente um paradoxo, pois na sociedade industrial não existe espaço para autores heróis, a não ser que esta visão ultrapassada ajude cada vez mais no acúmulo de capital. Por isso precisam ser, também, empreendedores, agentes que geram mais-valor. Caso contrário, não há espaço para eles no mercado capitalista. 
Por último, Rock analisa a "categoria" de "designers que usam o meio do design gráfico profissional para criar declarações e comparações auto referenciais" (ROCK, 1996, tradução nossa). Afirma que, nesse modelo, os designers operam em espaços entre projetos orientados para o serviço, mas também para a livre expressão. "Estes trabalhos evitam os parâmetros de um relacionamento com o cliente, ao mesmo tempo em que retém as formas ditadas pela necessidade do comércio" (Idem., Ibidem.). Ele exemplifica com o trabalho da designer April Greiman, que apresenta sua imagem nua, monocromática e com diversas colagens sobrepostas, num pôster em tamanho real, "com um texto pessoal cheio de sonhos e visões" (Idem., Ibidem). Mais uma vez se percebe a porosidade entre o Campo da Arte e o Campo do Design: o trabalho da designer parece estar muito mais próximo daqueles que habitam museus do que um trabalho de design, com função social concreta, no sentido de criar imagens e objetos que auxiliem para a ampliação de uma sociedade mais igualitária. Ademais, se percebe novamente a auto referência, desta vez na forma de autorretrato per se.

\section{2. O autor como produtor: idealismo em Benjamin e Lupton.}

Já foi sugerido por dois importantes teóricos do Campo da Arte e do Campo do Design tratar a autoria como produção, resultado de um trabalho, tal como se entende a produção de manufaturas: elas são o resultado do trabalho de um operário ou de um trabalhador. Um dos teóricos foi Walter Benjamin, importante ensaísta, crítico literário, tradutor, filósofo e sociólogo alemão, pertencente à famosa Escola de Frankfurt. Benjamin escreveu seu ensaio The author as producer endereçado ao Institute for the study of fascism, em 1934. A outra foi Ellen Lupton, designer, escritora, curadora, editora e educadora norte-americana. Lupton escreveu seu ensaio denominado The designer as producer para o livro The education of a graphic designer, em 1998, calcada no texto de Benjamim, mas dirigindo-o em outra direção. O recorte temporal dos dois textos é o mesmo (a Idade Moderna), mas o texto de Benjamim situa-se no conturbado período de recuperação dos estragos oriundos da quebra da bolsa de valores de 1929 e de uma Europa devastada pela Primeira Guerra Mundial, na véspera da ascensão do fascismo na Alemanha e 
toda a destruição que iria ocorrer. E o texto de Lupton, que foi escrito nas faldas da ascensão do neoliberalismo político e o gigantesco câmbio no modo de produção capitalista efetuado pelo Toyotismo, com vistas a maximizar a produção de maisvalor nos dias de hoje. No primeiro caso, a principal consequência foi a Segunda Guerra Mundial, assim como o holocausto e a Bomba $\mathrm{H}$ e hoje, se não considerarmos os fantásticos avanços científicos, tecnológicos e da produção da riqueza, houve uma ciclópica concentração de riqueza nas mãos de muito poucos, seguidas por uma nova crise do capitalismo em 2008 (muito mais devastadora que a crise de 1929) e o aumento da miséria e da pobreza para todo o planeta.

O pretendido no presente subcapítulo é fazer uma revisão bibliográfica crítica dos dois autores, gerando uma comparação entre diferentes tipos de idealismos em relação à produção de manufaturas, sejam manufaturas industriais, sejam aquelas que chamamos produtos do espírito, as artísticas ou culturais. Parece claro que a análise tenha que ser dividida por partes, visto o distanciamento histórico (sessenta e quatro anos separam os ensaios) e político, uma vez que Benjamin foi um escritor marxista (aqui trata-se do marxismo que pretendemos chamar de idealista, o que será explicado posteriormente) e Lupton pertence, no ponto de vista deste trabalho, ao idealismo liberal e carismático típico da contemporaneidade.

\section{Marxismo idealista em Benjamin.}

Benjamin (1934) começa seu ensaio citando a forma de Platão lidar com os poetas, ou seja, os banindo da pólis. Segundo Benjamin, Platão tinha uma alta concepção do poder dos poetas, mas acreditava que numa sociedade perfeita, isto é, para que a sociedade fosse uma república, não deveriam existir vozes individuais ou singulares, mas coletivas. Daí os poetas deveriam se sujeitar aos valores coletivos, caso contrário eles só poderiam ser prejudiciais e supérfluos aos membros da pólis. A seguir, Benjamin afirma que, desde então, a questão da expressão singular ou individual do poeta nunca mais foi posta com a mesma ênfase, mas que hoje ela se apresenta por si mesma. Narrando na primeira pessoa, Walter Benjamin questiona a autonomia do poeta em relação ao seu meio social e a contrapõe a sua 
liberdade de escrever ou de produzir o que quiser. Quebrando a quarta parede, ele afirma que "você [nós, os leitores] não está disposto a conceder a ele essa autonomia. Você acredita que a situação social atual o obriga a decidir em qual serviço ele deve colocar sua atividade" (BENJAMIN, 1934, p. 768). Continua alegando que o escritor burguês não reconhece essa escolha, e que devemos provar ao escritor que ele está trabalhando a serviço de interesses da classe burguesa, que é uma minoria em relação ao conjunto da sociedade industrial. O escritor mais avançado reconhece a escolha e, com base na luta de classes, ele deve apoiar o proletariado. Assim, o escritor põe fim à noção de autonomia ou independência do escritor burguês em relação ao meio social, e que sua atividade agora é decidida pelo que é útil para o proletariado na luta de classes.

Na visão moderna, a noção de Benjamim ou de Platão pode parecer ilógica, mas ela toca em um ponto essencial do trabalho do designer dentro da sociedade industrial: ele acredita que é um agente de produção independente e criador. Em um mundo que celebra a "expressão" individual do autor, a noção coletivista pode ser vista como censória ou restritiva à individualidade do homem moderno, contudo, podemos pensar que essa noção - de que as pessoas são livres para escolher - é um segredo de polichinelo, uma verdade que apenas o designer acredita que ainda não foi revelada, mas que na verdade todo mundo já tem conhecimento e finge acreditar.

O pensamento de Benjamin, até aqui, está diretamente alinhado com a hipótese do presente trabalho: a de que o autor trabalha e aquilo que produz, qual seja a sua manufatura espiritual, serve para o interesse da classe burguesa, e de que a noção de autoria como algo autônomo ao meio social é uma noção política e ideológica. Até aqui Benjamin fala do poeta e/ou do escritor, mas é fácil fazer uma comparação com o designer que trabalha para a classe burguesa e que não percebe que está servindo apenas a um pequeno grupo social, o qual embora afirme que sua produção se dedica ao humano - human centred ${ }^{33}$ - ou simplesmente ao usuário. Com isso, torna-se um trabalhador alienado, detendo um "estranhamento" $34 \mathrm{em}$ relação ao que produz, mas que confusamente acredita possuir total autonomia

\footnotetext{
33 Ver: MAGUIRE, Maritn. Methods to support human-centred design. In.: International Journal of Human-Computer Studies. Volume 55, Issue 4, October 2001, p. 587-634.

${ }^{34}$ MARX, Karl. Manuscritos Econômicos-Filosóficos. São Paulo, Boitempo, 2010. Especialmente p. 79-90.
} 
criativa para conceber seus trabalhos.

Mas acontece que Walter Benjamin defende que o escritor que escreve para o proletariado possui uma escrita dita tendenciosa (BENJAMIN, 1934, p. 768), embora esse sentido seja positivo, e afirma que: 1) um trabalho que mostra a tendência política correta não precisa de nenhuma outra qualidade, ou 2) que o trabalho que apresente uma tendência correta deve necessariamente ter qualquer outra qualidade. Para ele, a segunda formulação é a correta e que ele adota como dele. Sustenta que a sua intenção é promover um estudo sobre o fascismo utilizando essa prova, pois nem sempre o pensamento da maioria da pólis é positivo, mas pode ser deletério. A hipótese de Benjamin é a de que a tendência de um trabalho literário, uma manufatura criativa ou espiritual, pode ser politicamente correta apenas se for literariamente correta. "A tendência política correta de uma obra inclui, portanto, sua qualidade literária, porque inclui sua tendência literária" (Idem., p. 769, itálico no original). É a partir desse momento que se considera que o entendimento de Benjamin seja idealista ou mais precisamente, refere-se utopicamente ao trabalho, mas isso pode ser explicado por conta de sua luta contra a hegemonia do fascismo na Europa hitlerista, portanto trata-se de uma noção situada, ou seja, determinada por uma situação histórica concreta.

Ao formular que um trabalho literário só pode ser politicamente correto se for literariamente correto, isto é, seguindo suas próprias regras ou a tradição da arte da literatura, ou seja, tecnicamente ou formalmente bem-acabado de acordo como ele vem sendo realizado, Benjamin comete o mesmo equívoco teórico dos designers atidos ao utilitarismo funcional/tecnicista do movimento modernista (que, não por coincidência, dividiam o mesmo período histórico de Benjamin). Naquela época acreditavam que se a função do objeto de design fosse "correta", sua forma também o seria, ou seja, que a forma seguiria a função ou vice-versa. Até porque o "literariamente correto", noção que se julga camuflada ou ressentida, é um termo otimista, e Benjamin não elucida o que seria isto.

Benjamin continua seu discurso formalista/tecnicista:

Em vez de perguntar: "Qual é a atitude de uma obra para as relações de produção de seu tempo"? [talvez] gostaria de perguntar: "Qual é a sua posição nelas"? Esta questão diz respeito diretamente à função que a obra exerce nas relações literárias de produção de seu tempo. Trata-se, em outras palavras, 
diretamente da técnica literária das obras. (BENJAMIN, 1943, p. 770 , tradução nossa, itálico no original)

Para ele, trazendo a técnica à tona, ou seja, as regras da arte, ou tal como ela vem sendo realizada, nomeia o conceito que faz os produtos literários acessíveis para uma análise social e, portanto, materialista. Mas sabe-se, tal como aconteceu no meio industrial e na produção pesada em massa, que recorrer apenas à técnica como forma de atingir todas as classes sociais foi uma tentativa frustrada em diversos meios expressivos. Um exemplo foi o do Construtivismo russo, que se considerava universalista e previa que formas simplificas ou geometrizadas, cores básicas e sem nuances de tonalidades, poderiam alcançar todas as camadas sociais, dos mais pobres camponeses à alta burguesia. Na tentativa de colocar em prática esse movimento artístico, visivelmente influenciado pelos processos industriais daquela época, percebeu-se que, ao contrário do que esperavam, essa simplificação causava um distanciamento (portanto, a manutenção da luta de classes) entre aqueles que já haviam sido educados para entenderem esta e aquela forma mais moderna, enquanto que os menos abastados, aqueles que não tinham tido oportunidade de aprender aqueles códigos simbólicos, não tinham essa educação para compreendê-las. Seria o mesmo que dizer: algumas formas estavam presentes no habitus de certas classes e ausentes no habitus de outras. Desta maneira o Construtivismo russo caiu em desuso para dar espaço para o Realismo Socialista, que empregava o tradicional espaço figurativo do Renascimento, conjunto de códigos mais conhecidos, os códigos da tradição, consagrados ao longo dos anos. "Com sua concepção baseada no Realismo Socialista, os 'artistas proletários' [...] ganhavam mais força no combate às vanguardas, reproduzindo a ideologia do Estado, como propagandistas do partido" (MIGUEL apud. MATIAS, 2014, p. 49). Não é à toa que o Realismo Socialista foi reproduzido largamente nos anos seguintes por diversos países comunistas, abandonando totalmente o moderno estilo do movimento construtivista. É curioso como não perceberam como o Realismo Socialista era tão moderno quanto o Construtivismo russo, mas esse debate não será realizado aqui, pois foge ao escopo da proposta da ora dissertação.

Fica claro que, para Benjamin (1934), o “autor como produtor” é uma noção marxista, mas foi apropriada ingenuamente. Talvez ele não tenha tido tempo para desdobrá-la como deveria, afinal sua luta teórica naquela época exigisse um texto 
mais simplificado. Significa apenas o proletariado tomar para si os meios de produção, uma vez que os meios de produção deveriam pertencer aos trabalhadores que o utilizam (MARX, 2016). Para afirmar tal noção, Benjamin fez uma crítica à dois movimentos artísticos da intelligentsia de esquerda alemã da época: o Ativismo e a Nova Objetividade. Utilizou esses movimentos para demonstrar que "uma tendência política, por mais revolucionária que parecesse, tinha uma função contrarrevolucionária, desde que o escritor sentisse sua solidariedade com o proletariado apenas em suas atitudes, não como produtor" (BENJAMIN, 1934, p. 772, tradução nossa). Benjamin, assim como mais tarde Marcuse (apud. WOLFF, ver página 53), afirmou que o ativismo é um movimento reacionário, que tenta substituir a dialética marxista pelo senso comum. Uma noção que, para ele, não era quantificável em termos de classe. Já a Nova Objetividade fez da luta contra a pobreza um objeto de consumo.

\footnotetext{
A importância política do movimento foi de fato exaurida em muitos casos pela conversão de impulsos revolucionários, na medida em que ocorreram entre a burguesia, em objetos de distração, de diversão, que chegaram sem dificuldade aos negócios de cabarés das grandes cidades. (BENJAMIN, 1934, p. 776 , tradução nossa)
}

Se Benjamin enxergava candidamente o "autor como produtor" como uma espécie de ferramenta de tomada dos meios de produção pela classe proletária, veremos adiante que Ellen Lupton possui uma visão completamente diferente acerca do termo "produtor".

\section{Idealismo carismático em Lupton}

Ellen Lupton (1998) inaugurou seu breve ensaio denominado The designer as producer defendendo a ideia de que o slogan "designer como autor" gerou debates sobre o futuro da profissão do Designer Gráfico desde o início dos anos 1990. Segundo ela, a palavra autor sugeria "agência, intenção e criação em oposição às funções mais passivas de consultoria, estilo e formatação" (LUPTON, 1998, p. 159, tradução nossa). Lupton afirmava que os movimentos de vanguarda das duas primeiras décadas do século XX (fazia referência inclusive ao Construtivismo russo) criticaram o ideal de autoria "como um processo de dragagem de formas únicas das profundezas do eu interior" (Idem., Ibidem.). Para ela os artistas e 
intelectuais da época criticaram as noções românticas dos trabalhos de arte, "mergulhando nos mundos da mídia de massa e da produção em massa" (Idem., Ibidem.).

Para Lupton, produção é um conceito pertencente à história do modernismo e aqui sustenta-se que se trata de uma noção controversa. De modo geral defendese que estudar a história da humanidade é o mesmo que estudar a história da luta de classes, que, por sua vez, só pode existir em certo modo de produção e nesse caso no capitalismo (ainda que no período da acumulação primitiva algumas noções já estavam postas avant la lettre). Para muitos, o Modernismo como estilo ou movimento artístico surgiu com as vanguardas artísticas no final do século XIX e início do século XX, enquanto o pensamento sociológico marxista existe desde a primeira metade do século XIX, quando nem se imaginava o surgimento de tais vanguardas.

Lupton deixa a entender que se baseou nos escritos de Walter Benjamin (The author as producer), mas nada em seu texto propõe a visão materialista de Benjamin, enfim, ela é explicitamente parcial, defende um ponto de vista de classe (o seu), menosprezando aquilo que lhe era contraditório. Pelo contrário, em certo momento Lupton critica as ideias marxistas do autor:

Benjamin afirmou que, ao diminuir a distância entre autor e editor, autor e leitor, poeta e divulgador, trata-se de um ato revolucionário, porque desafia as categorias profissionais e econômicas sobre as quais as instituições de "literatura" e "arte" são erguidas. A ênfase marxista de Benjamin tem uma vantagem trágica quando vista do ponto de vista de hoje. Na época em que ele escreveu "O autor como produtor", a arte abstrata já estava em desacordo com o endosso de realismo social imposto por Stalin. Benjamin aplaudiu o Dada e o Surrealismo por desafiarem as instituições da arte e, no entanto, essas formas experimentais foram proibidas no Estado soviético que ele tanto admirava. A teoria de Benjamin sobre o autor como produtor permanece relevante hoje, no entanto, mesmo que se proponha desafios mais modestos às estruturas existentes de mídia e publicação, abrindo novos caminhos de acesso aos meios de manufatura e disseminação. (LUPTON, 1998, p. 161, tradução nossa)

Na citação acima percebe-se uma tentativa em desmerecer a visão de Walter Benjamin, fazendo uma relação um tanto quanto americanizada da noção marxista de Benjamin com o "endosso de realismo social" imposto por Stalin visto que, por 
exemplo, Stalin manteve o Lunatcharski no poder desde o proletkult ${ }^{35}$ dos primeiros tempos até a sua morte na França, em 1933.

\begin{abstract}
As novidades eram muitas, a começar pela não-intervenção estatal no campo das artes, uma das mais importantes contribuições de Lunatcharsky durante esse período inicial da revolução russa. Para os alunos era livre a entrada e a frequência, não sendo exigidos diplomas, conhecimentos prévios ou serem membros do partido bolchevique e a idade mínima exigida era de 16 anos. Não havia também provas para a admissão. (MIGUEL apud. MATIAS, 2014, p. 137).
\end{abstract}

Parece claro que tais comparações não condizem com a análise histórica e que a autora comete um deslize, ao comparar acontecimentos simultâneos díspares, desprovido de qualquer profundidade teórico-crítica.

Ela continua seu ensaio apresentando a relação entre Benjamin e o artista construtivista húngaro Laszlo Moholy-Nagi e o interesse que essa relação trouxe para Benjamin a respeito da tipografia. Segundo Lupton, Benjamin "previu" que o escritor iria compor seu trabalho com uma máquina de escrever ao invés da caneta, e que Benjamin teria escrito que "pode-se supor que novos sistemas com tipos de letra mais variáveis possam então ser necessários" (BENJAMIN, apud. LUPTON, 1998, p. 160). Daí Lupton dá um salto gigantesco totalmente interpretativo, desprovido de uma análise séria dos fatos: ela relaciona os "novos sistemas" de Benjamin com os softwares de processamento de texto e editoração eletrônica. Esse tipo de análise centrado no objeto, no elemento tecnológico, pode ser facilmente questionado no momento em que percebemos que não havia como Benjamin “prever” o salto tecnológico gigantesco que o mundo daria entre os anos 1980-90. Daí a relacionar uma eventual teoria "pós-moderna", caríssima aos neoliberais, com os escritos de Benjamin apenas para legitimar as suas noções parece, novamente, deveras irresponsável.

Com esta invertida radical de Lupton continua:

No contexto profissional do design gráfico, a "produção" está ligada à preparação da "obra de arte" para a reprodução mecânica, e não ao domínio intelectual do "design". A produção

\footnotetext{
${ }^{35}$ LUNATCHÁRSKI, Anatoli. Revolução, arte e cultura. (Orgs.) Douglas Estevam e Iná Camargo Costa. São Paulo: Expressão Popular, 2018. p. 26 - 33.
} 
pertence à atividade física da base, do chão de fábrica: é o domínio tradicional do artista, o stripper, o letterer, o tipógrafo. A revolução "desktop", que começou em meados da década de 1980, trouxe esses papéis de volta ao processo de design. A proletarização do design oferece aos designers uma nova fenda ao materialismo, uma chance de voltar a envolver os aspectos físicos do nosso trabalho. Enquanto o termo "autor", como "designer" sugere o funcionamento cerebral da mente, a produção privilegia a atividade do corpo. A produção está enraizada no mundo material. Valoriza as coisas em vez de ideias, fazendo sobre imaginação, prática sobre teoria. (Idem, p. 161, tradução nossa)

Não é a primeira vez entre os teóricos do campo que se depara com este tipo de pensamento: a ideia de que o produtor (ou o autor carismático) tem como consequência de seu trabalho apenas um "fazer", uma "atividade" e nunca daquilo que é, na realidade, um trabalho. Ou, o que é mais descabido (e a própria Lupton se contradiz mais à frente), uma diferenciação entre prática e teoria. Lupton defende que com a tal "revolução" do desktop o designer se "proletarizou", esquecendo-se de que o design não uma é manifestação de um espírito e nem um trabalho intelectual exercido por um profissional liberal. O trabalho do designer sempre foi o de um proletário, isto é, o trabalho de um trabalhador, que exerce o trabalho de um assalariado e que vende sua força de trabalho para os interesses burgueses. Ainda afirma que "a produção privilegia a atividade do corpo", a força muscular, física. Afirma que "o desafio hoje é ajudar os designers a se tornarem mestres, não escravos, da tecnologia". Parece lógico e também inquestionável que a tecnologia, por si só, não tem o poder de escravizar nada nem ninguém, pois ela é uma “coisa", um produto, um resultado de uma ação prévia e realizada por pessoas. Quem escraviza não é a tecnologia, mas o modo de produção, independentemente de suas tecnologias. São as instâncias de legitimação que consagram o modo de produção industrial.

Ela segue afirmando que existem oportunidades para tomar o controle dos meios de produção, e compartilhar esse controle com os usuários, capacitando-os a se tornarem produtores e consumidores de significado (Idem., p. 161). Sugere que as escolas, as instituições ou instâncias de recrutamento, formação, legitimação e reprodução dos saberes, que farão esse trabalho, sugerindo a linguagem (forma) como matéria-prima, isto é, a aplicação crédula apenas de uma técnica, um rito de acordo com um programa, a execução de um protocolo de acordo com um regime, 
um mero procedimento prático e isento de fundamentação teórica, tenha esse poder. Essa noção que sustenta o confuso princípio de que toda teoria é uma prática (aqui a contradição com a citação acima), que a escrita é uma ferramenta, que a tecnologia é física e que "o meio está no cardápio", em que os alunos devem ter acesso às ferramentas para encontrar o seu lugar de direito na cadeia alimentar.

A conclusão de Lupton é que o poder do termo "autor" (o executor individual de uma ação prática) está na sua conexão com o texto escrito, e que para que os designers se encarreguem da função social de seu trabalho, "não precisam se tornar escritores fluentes, não mais do que um diretor de arte deve se tornar um fotógrafo ou um ilustrador profissional para usar esses meios com eficácia" (Idem., p. 162). Ela parece desejar nos fazer acreditar que a coisa é simples: para nos encarregarmos individualmente da função social de nossos trabalhos, devemos ser escritores "medianos". E para isso usa como exemplo a direção de arte, o trabalho mergulhado nos dogmas da gestão e tão ao gosto do modo toyotista de produção, assim como dos tecnicistas da ideologia de mercado. 


\section{CONCLUSÃO}

Muitas foram as questões apresentadas na presente dissertação, que teve como objeto central de análise a noção de autoria que se julga aqui ser a hegemônica, ou seja, de que existe um agente social que produz suas "obras" com total autonomia, autoridade e individualismo. É dizer, entende-se, aqui, que é tido como senso comum pelos pares do campo (tanto aqueles que atuam e legitimam o pensamento nas universidades como aqueles que legitimam o pensamento no mercado onde o designer atua) que o agente social possua o "dom" inato da criatividade, e que através de uma "genialidade" produz objetos e imagens que não poderiam ser criadas por um ser humano "comum". O tão maior for essa genialidade, melhor serão os projetos de design e, consequentemente, o autor deverá possuir maior prestígio e capital simbólico entre os demais pares do campo.

Julga-se que tais noções são, como se afirma ao longo do texto, de cunho carismático. Este termo procura dar conta de ideias e ideais passadistas, em que se observa uma enorme variedade de profissionais do Campo do Design reproduzirem tal noção como se verdade absoluta fosse, e muito pouco se percebe discussões e análises um pouco mais aprofundadas sobre a noção de autoria. Quase na totalidade das vezes, o que se percebe são agentes de legitimação do campo afirmar e reproduzir essas crenças ultrapassadas sem nenhum (ou quase nenhum) aporte teórico-crítico com bases epistemológicas fortes. Tais agentes descrevem alguns designers como grandes influenciadores, criadores natos, que dão origem a uma nova maneira de projetar, e que tais agentes pouco ou nada tem a ver com a cultura material e com a sociedade industrial.

Examinou-se um pouco da história no que diz respeito às diversas noções de autoria ao longo das várias épocas, e se percebeu que nem sempre (na realidade na enorme maioria do tempo) as noções postas hoje em dia foram aceitas como verdadeiras. Analisou-se que a noção de autoria cambia de acordo com os diversos modos de produção e com seus respectivos agentes de legitimação. O que se pôde perceber foi que na grande parte dos períodos históricos o autor foi uma figura anônima. 
Na pré-história, o artista (importante lembrar que esse termo estava longe de ser cunhado nessa época, mas se utiliza tal termo por falta de um melhor) era um feiticeiro, que, através de poderes mágicos, materializava as coisas do além através da mágica, o que, em última análise, parece ser um comportamento bastante defendido pelos pares ainda nos dias de hoje, de certa forma. Com a sedentarização do homem e com a consequente criação das cidades-estados, o artista foi esquecido, pois o trabalho manual passou a ser visto como um trabalho "menor", principalmente se comparado ao trabalho dito intelectual. Não à toa que Platão, como visto anteriormente, se manifestou no sentido de banir os artistas da sociedade. Assim, muitos dos objetos da Antiguidade que são considerados hoje como obras de arte foram criados maiormente por escravos (maiormente porque existiu um período, na Grécia Clássica, em que foram referenciados e criticados alguns artistas, como Miron, Policleto e Fídias).

Depois, com a queda do Império Romano e com a desestruturação das cidades, as crenças pagãs e politeístas foram repudiadas, e os ideais cristãos tomaram conta Idade Média adentro. Em tal sociedade, em que quem detinha o monopólio do conhecimento era a Igreja, quem exercia a arte eram os monges em seus monastérios. Nesse período o anonimato era absoluto, e tudo que era construído tinha como função social a adoração a Deus. Em tal período não havia espaço para qualquer outro tipo de adoração, de forma a colocar o artista como um mero artesão que construía seus objetos e imagens anonimamente, o que faz por diferir em muito a noção de autoria da citada época (que era praticamente inexistente) com dias passados e os dias atuais.

Com o crescimento exponencial do poder da Igreja e com uma substancial demanda para a construção de enormes catedrais (entre outras obras) foi necessária a organização dos artistas em Corporações de Ofício, nas quais o trabalho era coletivo e as construções e configurações eram totalmente ditadas pelo poder da Igreja. É claro que, ainda nesse período, não havia ontologia social para a existência de um autor que se diferenciava dos outros construtores, como se gênio fosse.

Tudo começa a mudar, de maneira lenta e gradual (tal como os processos históricos se dão) no momento em que, com a revitalização econômica da Europa, começa a surgir a burguesia. Se for realizada uma comparação desse período daqui para frente com o anterior, verifica-se o consequente aumento da demanda por produtos. Nesse processo, que acabou por cambiar a forma como as relações 
humanas se davam, as loggias caíram, dando espaço, assim, para um artista mais individualizado. As formas de patrocínio, seja a Igreja ou os grandes Mecenas da época, agora eram lidadas diretamente com o "artista", e daí surgem as grandes figuras que, hoje, são chamadas com frequência de "gênios", como, por exemplo, Leonardo Da Vinci. Assim, de forma muito resumida, surge a separação, pela primeira vez, entre o artista e o artesão, em que o artista é o gênio que concebe ideias sobre-humanas e o artesão é apenas um reprodutor técnico com habilidade para reproduzir tais ideias. O que não se discute nas instâncias de consagração do conhecimento, isto é, nas escolas de design, é que essas noções não faziam parte da realidade social da época e que, diferentemente do que muitos acham, o artista renascentista não possuía o poder ou prestígio que lhes é concedido hoje. É dizer, os artistas não possuíam poder de escolha para realizar este ou aquele trabalho (que eram muito bem definidos pelos reais poderosos de então, seja a Igreja, sejam as cortes absolutistas) e também não eram tidos como agentes poderosos e especiais, e muitas vezes estavam muito mais próximos, socialmente, dos servis do que dos poderosos.

Com a tomada de poder pela burguesia em alguns lugares (visto que alguns sistemas feudais continuaram existindo até, pelo menos, a Primeira Grande Guerra) e, depois, com o advento da Revolução Industrial e com a divisão do trabalho, surge o sujeito social dominado pela noção individualista, conforme analisado no texto. Isso ocorre porque toda a sociedade começa a trocar um pensamento comunal por um ideal privado. Privatiza-se, dessa forma, também, o pensamento humano. Passa a vigorar a noção de que o pensamento era uma faculdade individual, exclusiva de alguns indivíduos. No meio do processo de individualização, no período em que se chama de Iluminismo, em que o homem foi colocado no centro do universo (através do racionalismo francês), surge a crítica de tal antropocentrismo, pois, para alguns, o homem era um ser passional, com níveis de profundidade que ele mesmo desconhecia. Esse sujeito é o sujeito romântico, tal como o jovem Werther, eternizado na obra de Goethe. O que se defende, aqui, e que já foi defendido por vários outros pensadores, é que o movimento romântico dá início à noção atual de gênio. Alguém que precisa necessariamente sofrer ou padecer com os dotes divinos que lhe foram oferecidos. Isto é, o homem não conseguiu se enxergar como tomador de decisão, e ainda precisava (e precisa) de um aporte divino para explicar as questões da individualidade. 
Paradoxalmente, com o crescente processo de industrialização, o trabalho humano começa a ser cada vez mais privatizado nas mãos de poucos, deixando insuficientes ou nenhum espaço para as tais noções românticas do trabalho em conjunto, de modo que o movimento que criticava o racionalismo acabou por desvanecer. Algumas ideias, contudo, permaneceram, e defendeu-se no presente trabalho que a noção carismática da autoria tem sua origem no movimento romântico. Mas tais questões possuem razão de ser.

Se a Revolução Industrial e sua forma de produção capitalista transformou o homem em sujeito privado, e a divisão do trabalho corroborou para essa transformação, parece lógico concluir que o trabalho de arte (que, conforme se percebeu durante esta dissertação, deu origem ao Campo do Design) se individualizou também e, como todas as outras formas de trabalho, passou a servir apenas para a produção de mercadorias com pouco (ou destituídas de) valor de uso e principalmente valor de troca simbólica. O que se percebe é que o artista, sem ter alternativa para vender sua força de trabalho, migrou para trabalhar na indústria, seja ela a da indústria da arte per se, que vende a altos custos a arte de alguns e deslegitima totalmente a de muitos, sejam artistas que migraram para trabalhar para a produção em série propriamente dita, como é o caso dos designers. Dessa forma, parece lógico que empregar um valor de "genialidade", seja para os artistas consagrados, seja para designers tidos como "autores" (tal qual se examina a noção neste trabalho) acaba por aumentar o valor de troca simbólica dos objetos da cultura material, gerando, assim, mais-valor, interesse principal do modo de produção industrial. É dizer, quanto mais "genial" for a mercadoria e maior "fama" tiver quem "assina" o trabalho, seja ele de arte, seja ele de design, maiores serão os preços nos pontos de venda de tais mercadorias e maior prestígio terá quem os comprar.

Relatou-se, também, que as formas de poder inculcam, com o intermédio do habitus e da Violência Simbólica, dirigindo-se para o crescimento de um campo parcial, tecnicista e, por fim, quase totalmente acrítico. Mergulhadas em ideais liberais, as instâncias de legitimação (as escolas de design) acabam por ensinar que o designer é: (i) um agente técnico, que tem o dever apenas de reproduzir aquilo que já existe, sendo mero executor dos briefings criados pelos donos das indústrias; ou (ii) um agente dotado de "poderes especiais", que se aproxima muito da noção moderna de artista e que, através de tais "poderes", emprega em suas “obras" total 
criatividade, criando objetos ou imagens totalmente inovadoras. Assim, cria-se um afastamento da realidade social em que se vive, uma vez que tais noções influenciam no pensamento de que o design é uma profissão ora para agentes que apenas reproduzem, ora para agentes dotados de genialidade (esta última sendo a noção adotada como objeto de crítica nesta dissertação), mas nunca como trabalhadores que devem possuir senso crítico, de forma a questionar esse status quo com a finalidade de construir uma Teoria Social do Design como uma forma de trabalho como qualquer outra, que possui demanda social concreta.

Analisou-se, também, a questão do fetichismo da mercadoria ou estranhamento da forma em relação ao trabalhador do Campo do Design. Percebeuse que o designer não cria ou inova, mas tem como função apenas diferenciar um objeto de outro. No processo de diferenciação, procura "camuflar" o que está subjacente em tais objetos: a produção de mais-valor. Argumenta ou materializa um eventual valor de uso social, quando se sabe que nada existe ali. Com efeito, essa diferenciação serve apenas para produzir mais-valor para as mercadorias fabricadas, e o quão mais conhecido, o mais famoso for o designer, maior será o valor simbólico dessas mercadorias, mais prestígio ou distinção social eles passarão a significar. E, uma vez distinto, mais fácil de ser vendido ou consumido; consequentemente, maior será, também, o mais-valor produzido em toda a cadeia de trabalho que envolveu a fabricação das mercadorias. Dessa forma, o profissional de design é, assim como todos os outros trabalhadores, um profissional alienado pelo modo de produção, que não se enxerga nos objetos que projeta e muitas vezes acaba por se decepcionar ao perceber, mas sem entender por que, não possui este poder na tomada de decisão. Isso mostra o quanto as relações capitalistas liberais de trabalho acabam por tornar o profissional de design em um agente dócil, que nada ou muito pouco questiona a ontologia de seu campo.

Outra noção examinada neste trabalho foi a de que o designer autor tem como função, também, a de criar ou reproduzir valores estéticos, empregando "boa forma" (Guteform) às mercadorias, o que está diretamente relacionado ao "bom gosto". Tal noção foi compreendida, novamente, como carismática e esvaziada de senso crítico, em que apenas se aceita a reprodução de antigos valores e nada se questiona. A crença de que os designers têm o "poder" de produzir mercadorias com valor de uso social e de que saibam por méritos próprios os meios para atender às demandas das pessoas, é compreendida hegemonicamente como se tivessem a 
capacidade e a liberdade para produzirem artefatos que possuam uma "boa forma". Essa noção também é vetusta e precisa ser ultrapassada. Parece lógico afirmar que, depois de um exame sociológico, toda escolha estética é uma escolha política, ou seja, não destituída de uma intencionalidade. Disso se segue que a "boa forma", o que é bonito ou não, é uma forma legitimada, de novo, através da simples reprodução dos valores instituídos. Isto é, por intermédio da Violência Simbólica, as matrizes culturais (habitus) são reproduzidas sem questionamentos, e o que é de "bom gosto", quase que na totalidade das vezes compreendido como algo de natureza subjetiva, é sempre legitimado pelas instâncias que habitam os orbitais de poder. Numa época foi a Igreja; noutra, as cortes absolutistas. E, hoje, na sociedade burguesa moderna, quem toma tais decisões é o agente social da classe burguesa, qual seja, o empresário e/ou dono de indústrias. Assim, uma eventual competência para identificar ou produzir artefatos possuidores de valores estéticos (e extra estéticos também) pertence a outra esfera. Trata-se de uma construção social que nada (ou muito pouco tem a ver) com a tomada de decisão do designer enquanto criador autoral, indivíduo privado, visto pelos pares como alguém especial que "inventa" formas "bonitas" e que dita o que é de "bom gosto" ou não.

A investigação da noção hegemônica do design autoral per se serviu primeiramente para concluir (o que já havia sido formulado como hipótese) que muito pouco se discute a respeito de tal noção dentro do Campo do Design. Percebeu-se que, em diversos outros campos da criação humana, se questiona e se escreve acerca disto que denominamos autoria. Mas, no Campo do Design (responsável pelos projetos de artefatos que deveriam ter valor de uso e que se tornam meras mercadorias), quase não há discussão sobre as crenças hegemônicas impostas. Parece claro que existe uma razão para a manutenção da falta de exame crítico a respeito de tais noções passadistas: como se disse anteriormente, a crença em seres dotados de capacidades geniais, opera no sentido de dotar as mercadorias de uma "aura", de que certas mercadorias são "especiais" por terem sido projetadas por esse ou aquele designer "famoso". E que tais designers contribuem para a permanência de tais crenças, pois, obviamente, ao se apropriarem de tal "genialidade", geram lucro para si e para as empresas para as quais trabalham.

Muito ainda deve ser discutido sobre a noção do designer enquanto autor. Uma das hipóteses defendidas nesta dissertação é a de que todo o trabalho é coletivo, ou seja, toda forma de trabalho depende das outras formas de trabalho, e 
que nenhum trabalhador realiza seu ofício de forma individual. É dizer, ninguém trabalha fora da estrutura capitalista dominante.

Assim, conclui-se que toda forma de autoria, enquanto discurso de "genialidade", "dom", trabalho individual, autônomo e autoritário, é ultrapassada, e serve apenas para que se legitimem valores burgueses e capitalistas. Tal entendimento sobre autoria acaba por induzir ao erro os trabalhadores do Campo do Design, fazendo-os acreditar que podem se tornar trabalhadores "especiais", "distintos", cheios de capital simbólico, contribuindo, assim, para a manutenção da já tão desgastada luta de classes. Há de se questionar, enfim, para quem ou para quê se está projetando. 


\section{REFERÊNCIAS BIBLIOGRÁFICAS}

ABBAGNANO, Nicola. Dicionário de Filosofia. São Paulo: Martins Fontes, 1998. ALPERS, Svetlana. O projeto de Rembrandt: o ateliê e o mercado. São Paulo; Companhia das letras, 2010.

BARTHES, Roland. O rumor da língua. 2. ed. São Paulo: Martins Fontes, 2004.

BECKER, Howard S. Mundos da Arte. Lisboa: Livros Horizonte, 2010.

BENJAMIN, Walter. A obra de arte na era da reprodutibilidade técnica. In.: Adorno et alii. Teoria da Cultura de Massa. São Paulo: Paz e Terra, 2000.

.The author as producer. Adress at the Institute for the Study of Fascism. Paris: 1934.

BURAWOY, Michael. O marxismo encontra Bourdieu. Campinas, São Paulo: Editora da Unicamp, 2010.

BOURDIEU, Pierre. O poder simbólico. Rio de Janeiro: Bertrand Brasil, 2003.

A economia das trocas simbólicas. São Paulo: Perspectiva, 2001.

BURKE, Peter. Testemunha ocular: o uso de imagens como evidência histórica. São Paulo: Editora Unesp, 2017.

CIPINIUK, Alberto. O Campo do Design e a crise do monopólio da crença. São Paulo: Blücher, 2017.

Design: o livro dos porquês: o campo do Design compreendido como produção social. Rio de Janeiro: Ed. PUC-Rio; São Paulo: Ed. Reflexão, 2014. CONTINO, Joana Martins et CIPINIUK, Alberto. Ideologia, divisão capitalista do trabalho e papel social do designer: um estudo sobre a produção de materialidade no design de moda In.: Revista Moda Palavra, volume 10, número 19, 2017. Trabalho apresentado no 12o Congresso Brasileiro de Pesquisa e Desenvolvimento em Design (P\&D Design), novembro de 2016.

DAVIS, Rebeca. Piers Plowman and the Book of Nature. Oxford: Oxford University Press, 2016.

EAGLETON, Terry. A Ideologia da Estética. Rio de Janeiro: Zahar, 1993.

ELIAS, Norbert. O Processo Civilizador. Rio de Janeiro: Zahar, 2003. 2 V.

A sociedade dos indivíduos. Rio de Janeiro: Zahar, 1994.

FIGUEIREDO, Luís Cláudio Mendonça. A invenção do psicológico: quatro séculos de subjetivação (1500-1900). 7.ed. São Paulo: Escuta, 2007. 
FOUCAULT, Michel. O que é um autor. Lisboa: Vega, 1992.

FORTY, Adrian. Objetos de desejo: design e sociedade desde 1750. São Paulo: Cosac Naify, 2007.

GIL, Antonio Carlos. Métodos e Técnicas de Pesquisa Social. São Paulo: Atlas, 1989.

HARVEY, David. Para entender O Capital. São Paulo: Boitempo, 2013.

. Condição pós-moderna: uma pesquisa sobre as origens da mudança cultural. São Paulo: Edições Loyola, 2010.

HAUSER, Arnold. História social da literatura e da arte. São Paulo: Mestre Jou: 1972-1982.

JAMESON, Fredric. Pós-modernismo: a lógica cultural do capitalismo tardio. São Paulo: Ática, 2007.

KING, Ross. Leonardo e a última ceia: uma biografia da obra-prima de Da Vinci. Rio de Janeiro: Record, 2018.

KOOP, Anatole. Quand le moderne n'était pas um style, mais une cause. Paris: École Nationale Supérieure des Beaux-Arts, 1988.

LUNATCHARSKI, Anatoli. Revolução, arte e cultura. (Orgs.) Douglas Estevam e Iná Camargo Costa. São Paulo: Expressão Popular, 2018.

LUPTON, Ellen. The designer as producer. 1998. Disponível em: $<$ http://www.typotheque.com/articles/the_designer_as_producer $>$. Acesso em: 08 set. 2019.

MAUGER, Gérard et alii. (Orgs.) Vocabulário Bourdieu. Belo Horizonte: Autêntica Editora, 2017.

MARX, Karl. O Capital: crítica da economia política: livro I: o processo de produção do capital/ Karl Marx; tradução Rubens Enderle - 2. Ed. - São Paulo: Boitempo, 2017.

Manuscritos Econômicos-Filosóficos. São Paulo: Boitempo, 2010.

MATIAS, Iraldo. Projeto e revolução: do fetichismo à gestão, uma crítica à teoria do design. Florianópolis: Editoria Em Debate/UFSC, 2014.

NOGUEIRA, Cláudio et alii. (Orgs.) Vocabulário Bourdieu. Belo Horizonte: Autêntica Editora, 2017.

OSINSKI, Dulce Regina Baggio. Arte, história e ensino: uma trajetória. São Paulo: Cortez, 2001. 
POYNOR, Rick. No more rules: graphic design and postmodernism. New Haven, Connecticut: Yale University Press, 2003.

RANCIÈRE, Jacques. Aesthesis. Scenes from the Aesthetic Regime of Art. Translated by Zakir Paul. London: Verso, 2013.

ROCK, Michael. The designer as author. In: BIERUT, Michael; DRENTTEL, William;HELLER, Steven (Ed.). Looking closer 4: critical writings on graphic design. New York: Allworth Press, 2002. p. 237-244.

SANTONI RUGIU, Antônio. Nostalgia do mestre artesão. Campinas: Autores Associados, 1998.

SCHLOSSER, Julius Von. La Littérature artistique: Manuel des sources de 1'histoire de l'art moderne. Trad. Jacques Chavy. Paris: Flammarion, 1984.

SELLE, Gert. Ideología y utopia del diseño. Barcelona: Gustavo Gili, S. A. 1973 SENNETT, Richard. O declínio do homem público. Rio de Janeiro: Record, 2016. O artífice. 2. ed. Rio de Janeiro: Record, 2009.

WOLFF, Janet. A Produção Social da Arte. Rio de Janeiro: Zahar, 1982. 